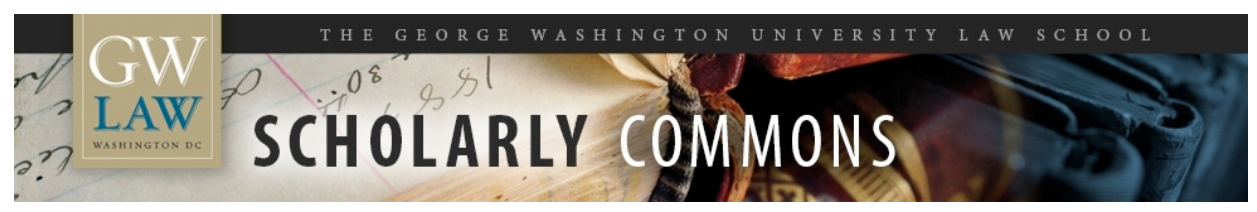

\title{
When Statutory Regimes Collide:Will Wisconsin Right to Life and Citizens United Invalidate Federal Tax Regulation of Campaign Activity?
}

\author{
Miriam Galston \\ George Washington University Law School, mgalston@law.gwu.edu
}

Follow this and additional works at: https://scholarship.law.gwu.edu/faculty_publications

Part of the Law Commons

\section{Recommended Citation}

Galston, Miriam, "When Statutory Regimes Collide:Will Wisconsin Right to Life and Citizens United Invalidate Federal Tax Regulation of Campaign Activity?" (2010). GW Law Faculty Publications \& Other Works. 594.

https://scholarship.law.gwu.edu/faculty_publications/594

This Article is brought to you for free and open access by the Faculty Scholarship at Scholarly Commons. It has been accepted for inclusion in GW Law Faculty Publications \& Other Works by an authorized administrator of Scholarly Commons. For more information, please contact spagel@law.gwu.edu. 


\title{
WHEN STATUTORY REGIMES COLLIDE: \\ WILL WISCONSIN RIGHT TO LIFE AND CITIZENS UNITED INVALIDATE FEDERALTAX REGULATION OF CAMPAIGN ACTIVITY?
}

\author{
Miriam Galston \\ Contact Information: \\ George Washington University Law School \\ 2000 H Street, N.W. \\ Washington, DC 20052 \\ 202-994-6781 \\ mgalston@law.gwu.edu
}

(C) by Miriam Galston. Do not quote or cite without author's permission. 


\section{TABLE OF CONTENTS}

INTRODUCTION ......................................................................

I. COMPETING VIEWS ABOUT ELECTION RELATED ACTIVITY SUBJECT TO GOVERNMENT REGULATION ..........................................4

A. The Expansive Tax Law Approach ................................4

B. The Minimalist Campaign Finance Law Approach ......7

II. ANTITHETICAL AGENCY METHODOLOGIES........................................13

A. The Tax Law Facts and Circumstances Approach .....13

B. The Campaign Finance Law Bright Line Approach ..15

III. JUDICIAL SCRUTINY: STRICT OR LIGHT ..........................................

A. The Deferential Tax Law Approach..........................17

B. The Heightened Scrutiny of Campaign Finance Law .22

IV. TAX LAW FIRST AMENDMENT JURISPRUDENCE APPLIED...............26

A. What Constitutes A Burden on Speech ......................26

B. The Political Prohibition Scrutinized ..........................32

C. Vagueness and Overbreadth Analysis ........................35

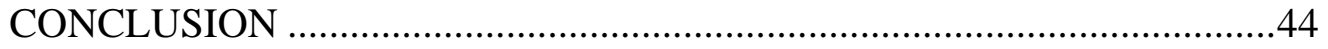




\section{INTRODUCTION}

It is now commonplace to see nonprofit ${ }^{1}$ organizations active during political campaigns. Churches invite candidates to give sermons on the eve of an election. ${ }^{2}$ Charities and other nonprofits fund politically charged issue ads ${ }^{3}$ and, in certain circumstances, register and mobilize voters. ${ }^{4}$ And nonprofits other than charities set up political action committees ("PACs") to support the candidacy of specific individuals running for election to public office. ${ }^{5}$

Most of these and similar activities are regulated by the Internal Revenue Code (the "Code"). ${ }^{6}$ If the nonprofit is exempt from federal income tax as a charity

1 Throughout this Article, I use the term "nonprofits" as a shorthand for "exempt organizations," i.e., nonprofit groups exempt from federal income tax under section 501 of the Internal Revenue Code. Technically speaking, however, groups obtain "nonprofit" status under state law, and not all state law nonprofits qualify as exempt organizations under federal tax law.

2 See Dan Gilgoff, Editorial, Turning a Blind Eye, IRS Enables Church Politicking, USA Today, January 29, 2007, at A13 ("most of us have become familiar with the sight of Democratic candidates addressing liberal African-American congregations from the pulpit”); Wayne Slater, Invisible Force Helping Huckabee: Largely Unknown Christian Leaders Prove Powerful in Iowa, Dallas Morning News, Dec. 24, 2007, at A1 (discussing the role sermons played in Mike Huckabee's campaign); Patrick L. O'Daniel, More Honored in the Breach: A Historical Perspective of the Permeable IRS Prohibition on Campaigning by Churches, 42 B.C.L. REV. 733, 736-39 (2001) (describing church activities during the 2000 presidential election).

3 Michael Riley, Political Funds Skirt Rules as Regulators Clamp Down on 527 Groups, Other Nonprofits Draw Donor Ads, Denver Post, Dec. 11, 2007, at B1 (discussing increases in funds for nonprofits to run "grassroots issues" ads due to restrictions on other organizations).

4 See e.g. Lynn Brezosky, Valley is Relatively Quiet About Election, San Antonio Express-News, November 3, 2008, at A8 (mentioning get-out-the-vote efforts by a group of six nonprofits). As is described below, detailed tax and campaign finance rules determine whether and how a particular nonprofit can engage in voter mobilization.

${ }^{5}$ For example, there is MoveOn.org Civic Action, which is a section 501(c)(4) organization, and MoveOn.org Political Action, which is its affiliated PAC, see http://www.moveon.org/about.html (last visited May 13, 2009); US Chamber of Commerce, a section 501(c)(6) organization, see http://www.uschamber.com, and US Chamber of Commerce PAC (NPAC), see http://herndon1.sdrdc.com/cgibin/fecimg/?C00082040 (last visited October 20, 2009). See also I.R.C. § 527(f); Senate Report No. 93-1357, 93 ${ }^{\text {rd }}$ Cong., 2d Sess. 30 (Dec. 16, 1974) (authorizing 501(c) groups to establish a connected PAC).

6 All references to the Code are to the Internal Revenue Code of 1954, as amended. Throughout this article, references to "tax law" refer to the federal income tax provisions in the Code and the associated regulations and administrative materials, 
described in section 501(c)(3), it is barred from intervening in political campaigns. ${ }^{7}$ Nonprofits described in other subsections of 501(c)-such as 501(c)(4) or 501(c)(6)-are generally permitted to intervene in campaigns, but the importance of their campaign activity relative to the activities fulfilling their exempt mission is restricted. ${ }^{8}$

In many instances, the campaign activities of nonprofit organizations are also subject to regulation by the Federal Election Campaign Act ("FECA"). ${ }^{9}$ The provisions of each of these two statutory regimes ${ }^{10}$-the Code and FECA--are very different, so that a specific campaign related activity engaged in by a nonprofit may be subject to campaign finance restrictions under FECA, but not subject to tax law restrictions under the Code, or the reverse. Alternatively, both statutes may regulate the scope or manner of a specific campaign related activity, but to different degrees or in different ways. Ultimately these differences can be traced to the fact that the two statutory regimes have been enacted to further distinct public purposes. That the two regimes are administered and enforced by different agencies, with differing missions, powers, and histories creates an additional layer of complexity.

Recent developments in campaign finance law have called into question the validity of the tax law restrictions on political campaign activity. In 2007, in Federal Election Commission v. Wisconsin Right to Life, ${ }^{11}$ the Supreme Court held that the First Amendment severely restricted the ability of Congress to use campaign finance law to regulate a particular type of political speech on the eve of a primary or an election. ${ }^{12}$ In 2010, in Citizens United v. Federal Election Commission, ${ }^{13}$ the Court went further and ruled that the prohibition in FECA against corporations engaging in campaign activity using their general treasury funds was unconstitutional because it banned protected political speech based upon the identity of the speaker. In both decisions, the Court articulated a First Amendment standard totally at odds with the First Amendment standard currently employed in the tax law area.

unless otherwise noted.

7 See I.R.C. § 501(c)(3); infra notes 18-20 and accompanying text.

8 See infra notes 22-25 and accompanying text.

9 See Federal Election Campaign Act of 1971, 2 U.S.C. $\S 431$ et. seq. (2000). Throughout this article, references to "campaign finance law" refer to this Act and the associated regulations and administrative materials, unless otherwise noted.

10 In this Article, the phrase "statutory regime" includes the rules created by the statute combined with the implementing regulations and administrative decisions and pronouncements, as these have been interpreted by the relevant agencies and the courts.

11551 U.S. 449, 127 S. Ct. 2652 (2007) (“WRTL”). Because there was a Supreme Court decision a year earlier involving the same advertisements, some commentators refer to the 2007 decision as "WRTL II."

12 See infra notes 39-45 and accompanying text.

13558 U.S. 175 L. Ed. 2d 753, 2010 U.S. LEXIS 766 (2010). 
These two recent campaign finance cases thus raise questions about the constitutionality of the federal tax law regulation of political campaign activities. The constitutionality of the tax restrictions on political activity was addressed only once before 2009. In Branch Ministries v. Rossotti, a decision involving a church that placed political ads in two national newspapers before the 1992 presidential election, the court upheld the tax law political intervention prohibition for 501(c)(3) organizations in the face of both free speech and free exercise challenges. ${ }^{14}$ In 2009, two lawsuits were filed challenging, inter alia, the constitutionality of the tax law restrictions as they apply to a 501(c)(3) organization and a 501(c)(4) group. ${ }^{15}$ Both complaints rely in part on the First Amendment standard announced in the campaign finance context in Wisconsin Right to Life. ${ }^{16}$

It is thus likely that in the next few years, the Supreme Court will address the constitutionality of the tax law restrictions on campaign activity, which often impose more severe limitations on campaign activity than is permitted under campaign finance law. This Article examines whether constitutional law doctrine developed in response to campaign finance restrictions on political speech must be applied to the parallel restrictions on the same type of speech imposed by tax law. The Article focuses on the prohibition preventing section 501(c)(3) organizations from political campaign activity, although much of the analysis would also apply to the less restrictive limitations on the campaign activities of other groups described in section 501(c). I conclude that importing the campaign finance First Amendment standard into tax law First Amendment jurisprudence is not required as a matter of constitutional law because the constitutional principles underlying the two spheres are fundamentally different, permitting more intrusive regulation by the tax Code than by FECA.

Parts I-III discuss three critical areas in which the campaign finance regime and the federal tax regime can produce inconsistent results for nonprofits active

14 Branch Ministries et al. v. Rossotti, 211 F.3d 137 (D.C. Cir. 2000) and infra notes 143 and 162 and accompanying text. For the free exercise claim, see id. at 142-43; for the free speech claim, see id. at 143-44. See also Branch Ministries, Inc. v. Rossotti, 40 F. Supp. 2d 15, 26-27. The Supreme Court upheld the arguably parallel tax law restrictions on lobbying by charities in Regan v. Taxation with Representation of Washington, 461 U.S. 540 (1983) (“TWR”).

15 See Christian Coalition of Florida, Inc. v. United States, US District Court, Middle District of Florida, Ocala Division, Civil Action No. 5:09-cv-00144-WTH-GRJ (the 501(c)(4) case); Catholic Answers, Inc. and Karl Keating v. United States, U.S. District Court for the Southern District of California, Civil Action No. 3:09-cv-00670IEG-AJB (the 501(c)(3) case). Both of these complaints also rely upon Big Mama Rag, Inc. v. U.S., 631 F.2d 1030 (D.C. Cir. 1980). For the trial court decision, see Catholic Answers v. U.S., 2009-2 U.S. Tax Cas. (CCH) \50,697, 104 A.F.T.R.2d (RIA) 6894 (S.D. Cal. 2009), appeal docketed, No. 09-56926 (9th Cir. Dec. 4, 2009).

16 Complaint, Christian Coalition of Florida, at I 64; Complaint, Catholic Answers, at $₫ 31$. 
during political campaigns: (1) the categories of election-related activity that may be restricted, (2) the proper method for agencies to use to determine if a group's activities have in fact violated a valid legal restriction, and (3) the level of scrutiny a court will employ to determine if a restriction violates constitutional norms. These three issues were central to the reasoning in Wisconsin Right to Life and Citizens United, and they will undoubtedly provide the framework for determining the constitutionality of the restrictions on political campaign activity contained in the tax law.

Part IV analyzes how the doctrines of traditional tax jurisprudence discussed in Parts I-III are likely to be applied to the political prohibition preventing 501(c)(3) organizations from participating in political campaigns. It concludes that under existing tax law jurisprudence, which the campaign finance cases are unlikely to alter, the impact of the political prohibition will not be deemed a burden as a matter of constitutional law. This is the case even if the organizations in question might suffer economically from a loss of revenues if they were to forgo tax exemption in order to be involved in political campaigns. Part IV then analyzes the political prohibition in light of the rational relation test and concludes that theprohibition's purpose and the means chosen to achieve that purpose are likely to pass constitutional muster.

The last section of Part IV examines the possibility that the political prohibition may be deemed unconstitutionally vague or overbroad because of the lack of precision in the terms of the prohibition and the authorities elaborating their meaning. It concludes that the Supreme Court might assess these questions using a form of heightened scrutiny and that the outcome, in such an event, is less certain than the outcome of the previous inquiry. Thus, although it seems that the balance of authorities favor upholding the political prohibition in the tax law despite the dramatic changes made by the recent campaign finance cases, some ambiguity remains as to the constitutional validity of the political prohibition in the tax law as it is currently interpreted.

\section{THE COMPETING REGIMES: CATEGORIES OF ELECTION RELATED ACTIVITY SUBJECT TO GOVERNMENT REGULATION}

\section{A. The Expansive Tax Law Approach}

Since 1954, the Internal Revenue Code has prohibited charities ${ }^{17}$ from participating or intervening in political campaigns. ${ }^{18}$ The implementing Treasury regulations add that the prohibition applies to indirect as well as direct political

17 "Charities" is shorthand for organizations described in section 501(c)(3) of the Code and exempt from federal income tax because of their educational, religious, scientific, etc., activities.

18 See I.R.C.§ 501(c)(3). 
participation. $^{19}$ The statute specifically states that publishing and distributing statements count as intervention and that activity taken in opposition to a candidate counts to the same degree as activity in support of a candidate. ${ }^{20}$ The prohibition was added to the description of charitable entities in 1954 as a result of a floor amendment proposed by then Senator Lyndon Johnson, but the legislative history is silent as to the reason for or scope of the provision. ${ }^{21}$

In contrast to charities, organizations described in other subsections of section 501(c) are permitted to participate or intervene in political campaigns. These include social welfare and civic organizations described in section 501(c)(4), labor organizations described in section 501(c)(5), and trade associations described in section 501(c)(6). ${ }^{22}$ However, such organizations must be primarily engaged in promoting the mission that is the basis of their respective exemptions. Campaign activities are not considered to promote an exempt purpose for any of the subsections of section 501(c). ${ }^{23}$ Thus, 501(c) organizations other than charities are permitted to engage in campaign activities, but if these become extensive enough, they can undermine an organization's claim to be devoted primarily to its exempt purpose.

\footnotetext{
19 Treas. Reg. § 1.501(c)(3)-1(b)(3)(ii), -1(c)(3)(iii) (2008).
}

I.R.C.§ 501(c)(3). Until 1987, the statute did not contain the parenthetical "or in opposition to.” See Pub. L. 100-203, 101 Stat. 1330-464, §19711. However, campaign activity was always understood to include both support and opposition to a candidate for public office.

21 See H.R. 7835, 73 ${ }^{\text {rd }}$ Cong. (1934), §§ 101(6), 406; Marie B. Morris \& Thomas B. Ripy, Limits on Lobbying and Political Activity by Tax-Exempt Organizations: Historical Background and Continuing Issues, CONGRESSIONAL RESEARCH SERVICE REPORT 3 (March 10, 1987). Only the lobbying limitation was enacted into law in 1934. A provision limiting charities' participation in "partisan politics" was approved by the Senate in 1934 at the same time as the counterpart provision limiting the extent of lobbying permitted to charities was enacted, but the political participation provision was not enacted into law, and it is unclear why the prohibition against engaging in partisan politics was dropped. Both provisions may have been inspired by an earlier court decision stating that "political agitation" should not be paid for by "public subvention.” Slee v. Comm'r, 42 F.2d 184, 185 (2d Cir. 1930). For theories regarding the origin of Johnson's amendment, see Chris Kemmitt, RFRA, Churches and the IRS: Reconsidering the Legal Boundaries of Church Activity in the Political Sphere, 43 HARV. J. ON LEGIS. 145, 152-53 (2006); O’Daniel, supra note 2, at 746-67; Oliver A. Houck, On the Limits of Charity: Lobbying, Litigation, and Electoral Politics under the Internal Revenue Code, 69 BRoOK. L. REv. 1, 23-29 (2003/04); Deirdre Halloran \& Kevin Kearney, Federal Tax Code Restrictions on Church Political Activity, 38 CATH. LAW. 105, 106-08 (1998).

22 See IRS Fact Sheet 97-8, 1997 IRB LEXIS 85 (1997).

23 See Treas. Reg. § 1.501(c)(4)-1(a)(2); I.R.S. Gen. Couns. Mem. 36286 (May 22, 1975); I.R.S. Fact Sheet 97-8, 1997 IRB LEXIS 85, Feb. 1997. In contrast, campaign activities are the core of the exempt purpose of section 527 groups. See I.R.C. § 527(e). 
Moreover, private benefit and certain commercial transactions, if any exist, must be aggregated with the group's campaign intervention to determine if the group is organized and operating primarily for its exempt purpose. ${ }^{24}$ In addition to these limitations on the relationship between their campaign activity and their exempt purpose, such organizations may also be subject to a tax calculated using the dollar amount of their campaign expenditures as a base. $^{25}$

Thus, all 501(c) exempt organizations are subject to restrictions on their campaign activity. Because the Code and the implementing Treasury regulations do not elaborate which election related activities qualify as "participating or intervening in political campaigns," the meaning of these terms must be derived from various Revenue Rulings, an assortment of other administrative pronouncements, and a few court cases. These authorities elaborate an expansive view of the types of election related activity that may be subject to the tax law restrictions. In addition to the obvious culprits, such as communicating or funding a message that expressly endorses a specific candidate or contributing to a candidate's campaign, the Service also classifies as campaign intervention all activities that support or oppose a candidate for office or otherwise intervene in an election, indirectly as well as directly. For example, the New York City Bar Association's practice of rating candidates running for election as judge on a nonpartisan basis disqualified it from receiving exempt status as a 501(c)(3) organization. ${ }^{26}$ Despite the fact that the association often gave multiple competing candidates the same highest rating and political party played no

24 The "primarily" standard is undefined and controversial. When litigating against social welfare organizations, the I.R.S. has repeatedly argued that the primarily standard means that a group's non-social welfare activities cannot be "substantial." See Vision Services Plan v. U.S., 2006-1 U.S.T.C. ๆ 50,173, aff'd 2008-1 U.S.T.C. ๆ 50,160, cert. denied 129 S. Ct. 898 (2009); Vision Service Plan, Inc. v. U.S., Brief for the United States in Opposition to the Petition for a Writ of Certiori, p. 8. In other forums, the Service has adopted less restrictive standards, e.g., that a social welfare organization is entitled to exemption even if $49 \%$ of its activities are not devoted to social welfare. See, e.g., I.R.S. Fact Sheet 97-8, 1997 IRB Lexis 85, Feb. 1997; I.R.S. Gen. Couns. Mem. 34233 (Dec. 3, 1969); I.R.S. Gen. Couns. Mem. 36286, supra note 23. Whatever the standard, the IRS may measure more than the percentage of a group's expenditures for election activities, as it does with the lobbying standard, which looks at the importance of lobbying for a group's mission as well as to the amount of lobbying. See Haswell v. U.S., 500 F.2d 1133 (Ct. Cl. 1974), cert. denied, 419 U.S. 1107 (1975); Nationalist Movement v. Comm'r, 102 Tax Ct. 558, 589 (1994), affirmed on other grounds, 37 F.3d 216 (5 ${ }^{\text {th }}$ Cir. 1994), cert. denied, 513 U.S. 1192 (1995).

25 See I.R.C. §527(f)(1). Section 527(f)(1) provides that the tax will be assessed on the lesser of the amount of a group's campaign expenditures or its net investment income. Groups with little net investment income will thus have relatively little tax exposure no matter how much they spend on campaign activities.

${ }^{26}$ See Association of the Bar of the City of New York v. Commissioner, 858 F.2d 876 (2d Cir. 1988), cert. denied, 490 U.S. 1030 (1989). 
role in its evaluations, the Service determined that the act of rating candidates for elective office constituted intervention in a political campaign. ${ }^{27}$

The IRS may find a public forum that includes all the candidates for a particular office $^{28}$ nonpartisan and thus not subject to these restrictions. The forum may, however, be classified as campaign activity if the content of the questions, the format of the forum, or anything else appears to favor or disfavor one candidate in comparison to the others. ${ }^{29}$ Similarly, a 501(c)(3) organization may invite candidates to speak at group functions, but only if it invites competing candidates to functions of comparable importance to the host group. ${ }^{30}$ This limitation does not apply, however, if a candidate is invited to a group's function in a capacity other than as a candidate, e.g., as a spokesperson for a particular issue. ${ }^{31}$ Questionnaires sent to candidates and disseminated to voters or the publication of voting records may be nonpartisan or they may evidence bias and thus constitute prohibited campaign activity. Bias, according to the Service, can be inferred by the narrowness of the subjects covered, the timing of the distribution, or the extent of the distribution as well as by editorial content. ${ }^{32}$

In short, under the tax law, diverse activities and communications, none of which is an express endorsement of one or more candidates for public office, may constitute political intervention of the kind that is prohibited to 501(c)(3) organizations and subject to restrictions in the case of other groups exempt under Code section 501(c).

\section{B. The Minimalist Campaign Finance Law Approach}

Traditionally, the three main types of federal campaign finance regulation were disclosure rules (primarily registration and reporting rules); limitations on the

27 See Bar of the City of New York, supra note 26, at 880-82.

28 It is unnecessary to include all candidates, however. See Judith E. Kindell and John Francis Reilly, Election Year Issues, in IRS, EXEMPT ORGANIZATIONS TECHNICAL

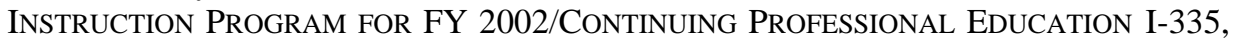
374 (2002) (hereinafter $2002 \mathrm{CPE})$.

29 Rev. Rul. 86-95, 1986-2 CUM. BuLL. 73, explicitly mentions facts and circumstances "establishing” a neutral manner. Rev. Rul. 74-574 notes that, despite inviting all candidates, if the format or questions "show a bias or a preference for or against a particular candidate," the forum will not be considered neutral.

30 See Rev. Rul. 2007-41, 2007-1 CuM. BuLL.1421, 1423 (Situations 7-9); Kindell \& Reilly, supra note 28, at 381.

31 See Rev. Rul. 2007-41, supra note 30, at 1423-24; Kindell \& Reilly, supra note 28, at 381-82.

32 Rev. Rul. 78-248, 1978-1 CuM. Bull. 154; Rev. Rul. 80-282, 1980-2 CuM. Bull. 178. For other factors affecting whether election related activities will be characterized as political intervention, see infra Part II.A. 
amount that individuals and entities can contribute in a year or election cycle to candidates and parties or to their committees (the "amount" rules); and prohibitions on corporations and unions spending money from their general funds for certain types of election related speech (the "source" rules). In 2010, in Citizens United, the Supreme Court invalidated the source rules for corporations (and, by implication, for unions) making independent expenditures, although it upheld the disclosure rules applicable to such expenditures and did not address the validity of the rules preventing corporations and unions from making political contributions. ${ }^{33}$

The categories of campaign activity subject to regulation by FECA are for the most part precisely and narrowly defined, a fact usually explained in terms of First Amendment considerations. Specifically, the Supreme Court takes the view that campaign related speech is core political speech that is protected by the First Amendment of the Constitution and essential to the successful working of democratic processes. $^{34}$ When such speech is burdened by regulation, the government must justify its action by demonstrating a sufficiently strong state interest and persuading the Court that the restrictions imposed are designed to accomplish that interest in a fashion no broader than the Constitution permits. ${ }^{35}$

As elaborated by the courts, the First Amendment protection of political speech permits regulations instituted to prevent corruption or the appearance of corruption in elections, although not to equalize the resources available to different participants in the political process. Campaign contributions are the most heavily regulated activities by FECA because they involve transfers made directly to candidates or parties and, thus, are most likely to leave the recipients feeling indebted to the donors. ${ }^{36}$ In contrast, funds spent by people or organizations independent of a campaign and spent independently of the campaign are subject to the least amount of regulation.. According to the Supreme Court in Buckley, the reason is that, if the individual or group paying for a political communication during a campaign acts independent of candidates and political parties, the risk of corruption is less likely than with campaign contributions because the candidate and party will not control the timing or content of the communication and might even find it unhelpful. ${ }^{37}$

33 See supra note 13.

34 See Buckley v. Valeo, 424 U.S. 1, 14 (1976) (per curiam).

35 The Court will applies two distinct levels of heightened scrutiny, depending upon the type of campaign activity involved and the degree to which the speaker's speech is burdened. These are discussed infra Part III.

36 See Buckley, supra note 34, at 25-28; Error! Main Document Only.United States v. Automobile Workers, 352 U.S. 567, 577-578 (1957) (quoting a Senator stating that large contributions make political parties feel obligated to the donors). Cf. id. at 29-30.

37 Buckley, supra note 34, at 47. There is a disconnect between the theory, which has no empirical support, and reality. Presumably when donors give millions to non-registered 527 groups, which are not subject to FECA source and amount rules even though they are known to support specific candidates or parties, the candidates benefited notice and can be 
The threat of corruption is nonetheless real when independent expenditures ${ }^{38}$ are made to endorse a specific candidate, since express endorsements are likely, or would appear likely, to make the candidate feel beholden to the source of funds spent so visibly on his or her behalf. ${ }^{39}$ In short, the feeling of being beholden to a contributor, or political debt, is viewed as the petri dish in which corruption, or the appearance of corruption, is nourished. Thus, although it struck down proposed dollar limits on independent expenditures, the Buckley Court upheld FECA's independent expenditure disclosure rules "to achieve through publicity the maximum deterrence to corruption and undue influence possible" in addition to its role in providing voters with information about sources of funding. ${ }^{40}$ Of course, if individuals or groups coordinate their activities with candidates, political parties, or their committees, the possibility of corruption or the appearance of corruption is treated by campaign finance law the same as if the funds were actually contributed to those who benefit because coordinated actions are likely to create, or appear to create political debt to the same degree as direct contributions. ${ }^{41}$

Kennedy's opinion in Citizens United, in contrast to the Buckley opinion, made a point of emphasizing the informational value of disclosure to the exclusion of its role in deterring corruption. ${ }^{42}$ This may be due to the Citizens United majority's

expected to feel indebted.

38 Although FECA does not define people who are independent, it does define "independent expenditures" as funds used for express advocacy of a candidate for federal office if they are "not made in concert or cooperation with or at the request or suggestion of such candidate, the candidate's authorized political committee or its agents, or a political party committee or its agents.” 2 U.S.C. § 431(17). See 11 C.F.R § 109.21(d).

39 See Buckley, supra note 34, at 27-28, 45. The Court does not categorically declare this is the case, and its holding only assumes the proposition's validity "arguendo." But this is the clear implication of the Court's comment that expenditure limits limited to express advocacy would leave a "loophole" for those seeking to exert "improper influence" on a candidate through large expenditures of money. Id. at 45. The Court's prediction, of course, has proved correct. Further, it is common for those who make contributions or expenditures classified as "independent" under FECA to have significant ties to the candidates or parties they are supporting. See, e.g., McConnell v. FEC, 540 U.S. 93, 153 (2003) (noting, as a matter of law, Congress's concern that access to a candidate can be "sold" even by a group independent of the candidate and his or her campaign), id., at 156 n.51; SpeechNow.org v. FEC, 567 F. Supp. 2d 70, 75 (D.D.C. 2008) (noting the "close relationships between party operatives and the persons running prominent 527 organizations (who were in some instances one and the same)," although they did not "violate[...] the letter of the law on independence and non-coordination"), id. at 80.

40 Buckley, supra note 34, at 76. See id. at 66-67; FEC v. Colo. Republican Fed. Camp. Committee, 533 U.S. 431, 433 (2001).

41 See Buckley, supra note 34, at 46-47.

42 See Citizens United, supra note 13, at *95 (referring only to the first of Buckley's three justifications for disclosure) with id. at $* 100$ (stating that the Court will not examine "the Government's other asserted interests" because the informational function alone justifies the disclosure provision). There is nothing in the Buckley 
desire to place new limits on the meaning of corruption for campaign finance purposes, specifically to limit corruption to quid pro quo arrangements. ${ }^{43}$ Buckley had portrayed "undue influence" as a part of the corruption that campaign finance regulations could legitimately deter, ${ }^{44}$ and several subsequent Supreme Courts echoed the view that quid pro quo does not exhaust the meaning of corruption. ${ }^{45}$ However, the Citizens United opinion referred to corruption exclusively in terms of quid pro quo exchanges, ${ }^{46}$ and several Justices making up the Citizens United majority have explicitly limited the concept in that fashion. ${ }^{47}$

Until the Citizens United decision was handed down, FECA's “source” rules prohibited corporations and labor organizations from spending money from their corporate or union general treasuries on express advocacy or electioneering communications. ${ }^{48}$ They were, however, free to spend unlimited amounts of money from their general treasuries on all kinds of election related communications and activities other than these two types of political speech. The force of the general treasury funding restriction was severely narrowed in 2007 by Wisconsin Right to Life, ${ }^{49}$ and in 2010 Citizens United invalidated the general treasury funding restriction

passage to suggest that the Buckley Court considered each of the three justifications listed to provide sufficient justification for the burden imposed by disclosure rules. See supra note 39.

43 See Citizens United, supra note 13, at *83-87.

44 See supra note 40 and accompanying text.

45 See Nixon v. Shrink Mo. Gov’t PAC, 528 U.S. 377, 388-389 (2000); Colo. Republican Fed. Camp. Committee, supra note 40, at 441; McConnell, supra note 39, at $143,150,152$.

46 See supra note 42 and Citizens United, supra note 13, at*60, *79, *80. For the dissent's interpretation of the corruption precedents, see id. at *239-62.

47 See McConnell, supra note 39, at 290-293 (Kennedy, J., with whom Justices Scalia and Thomas joined, concurring in part and dissenting in part) (arguing that Buckley limited the government's compelling interest to quid pro quo corruption and citing Citizens Against Rent Control/Coalition for Fair Housing v. Berkeley, 454 U.S. 290, 297 (1981) for this interpretation). See also Campaign Finance Disclosure and the Legislative Process, 47 HARV. J. ON LEGIS 75, 92-95 (2010).

48 See 2 U.S.C. $\S 441 \mathrm{~b}(\mathrm{a}),(\mathrm{b})(2)$. Buckley, supra note 34, at 43-44, appeared to assume the validity of the provision as it relates to express advocacy, as did FEC v. Massachusetts Citizens for Life, Inc., 479 U.S. 238 (1986), and FEC v. Beaumont, 539 U.S. 146 (2003). McConnell, supra note 39, which upheld the electioneering communication provision against a facial challenge, also assumed the validity of the source prohibition relating to express advocacy, as did WRTL, which linked the electioneering communication provision of FECA to communications that were the functional equivalent of express advocacy. The phrases "general treasury" and "general treasury funds" refer to an entity's funds resulting from its business operations; these terms are contrasted, inter alia, with funds it raises for an affiliated political action committee ("PAC"). Corporations and unions were able to fund express advocacy and electioneering communications through their PACs.

49 See WRTL, supra note 11, at 2667, which narrowed the meaning of "electioneering 
completely. ${ }^{50}$ As a result, corporations and unions are now permitted to use the revenue accumulated from their business operations to fund express advocacy or any other kind of campaign speech. This development not only erased the source restrictions on federal campaign financing. According to Professor Daniel Ortiz, as a practical matter, it undermined FECA's restrictions on soft money ${ }^{51}$ as well, by enabling corporations to spend business revenue on ads in the pre-election period that avoid express advocacy and by creating doubt as to the constitutionality of the soft money provisions themselves. ${ }^{52}$

There is, then, a stark contrast between the breadth of the conception of campaign related speech subject to regulation for purposes of the federal tax law and the counterpart concept subject to federal campaign finance law. For campaign finance law purposes, it is unclear whether any campaign related speech that is not coordinated with a candidate or a political party can be subject to federal campaign

communications" to instances in which the communication is also express advocacy or its "functional equivalent."

50 See Citizens United, supra note 13 (overruling McConnell, supra note 39, as it applied to electioneering communications and Austin v. Michigan State Chamber of Commerce, 494 U.S. 652 (1990), as it applied to independent corporate spending ). Many commentators had concluded that WRTL effectively overruled the electioneering communication portion of McConnell. See Christopher J. Peters, Under-the-Table Overruling, 54 WAYNE L. REV. 1067, 1070 (2008) (stating that WRTL "gutted McConnell's conclusion" that the electioneering communication provision was not unconstitutionally broad); Daniel R. Ortiz, The Difference Two Justices Make: FEC v. Wisconsin Right to Life, Inc. II and the Destabilization of Campaign Finance Regulation, 1 ALBANY GOV'T L. REV. 141, 142 (2008) (asserting that the holding in WRTL II "robs the [electioneering communication] ban of any content"); Richard L. Hasen, Beyond Incoherence: The Roberts Court's Deregulatory Turn in FEC $v$ Wisconsin Right to Life, 92 n MiNN. L. REV. 1064, 1065 (2007) (stating that WRTL "mostly eviscerated" the ban on corporate and union soft money funding for preelection sham issue ads). Seven justices in Wisconsin Right to Life agreed that the formula articulated by the WRTL plurality opinion amounted to overruling McConnell. See WRTL, supra note 11, at 2683 n.7 (Scalia, J., concurring in the result), 2699-2700 (Souter, J., dissenting). According to Samuel Issacharoff, the WRTL decision signaled that the Court was "poised once again to make a decisive move against Buckley." The Constitutional Logic of Campaign Finance Regulation, 36 PEPPERDINE L. REV. 373, 374 (2009). So far, the Court has framed its actions as strengthening Buckley by overruling precedents unfaithful to Buckley's teachings.

51 "Soft money" refers to contributions that can be raised without satisfying FECA's disclosure, amount, and source rules. See McConnell, supra note 39, at 122-123. It is also sometimes referred to as "non-federal" or "unregulated" money. "Issue ads" can be paid for by "soft," i.e., unregulated money, in contrast to "express advocacy," which had to be paid for with "hard" money, i.e., money subject to FECA disclosure, amount, and source restrictions. See Buckley, supra note 34, at 66-68 (employing strict scrutiny to evaluate the constitutionality of disclosure rules); Massachusetts Citizens for Life, supra note 48, at 252-53 (same).

52 See Ortiz, supra note 50, at 162-163. 
finance regulation. $^{53}$ The theory appears to be that, if the support of candidates or political parties is communicated independent of them, the First Amendment protects it from everything except disclosure regulation. Under federal income tax law, in contrast, not only express advocacy, but any campaign related speech or other action that supports or opposes a candidate for public office may be subject to restrictions, depending on the facts and circumstances of the case.

\section{ANTITHETICAL AGENCY METHODOLOGIES}

\section{A. The Tax Law Facts and Circumstances Approach}

As was noted earlier, there are few bright line rules to follow to determine whether a given election related activity falls within the tax law's capacious understanding of political campaign activity. ${ }^{54}$ From the time of its earliest rulings in this area, the Service has taken the position that it will look at all of the facts and circumstances surrounding an activity to determine if it is prohibited to 501(c)(3) organizations or restricted to other groups exempt under section 501 of the Code. Making these determinations, of course, can involve the agency in complex and nuanced examinations.

The character of the Service's facts and circumstances test is captured by a Revenue Ruling issued in 2004. ${ }^{55}$ The ruling sets out six situations in which an organization exempt under section 501(c)(4), 501(c)(5), or 501(c)(6) funds one or more radio or print advertisements in the weeks preceding an election. Several additional facts are common to all six situations. In each, the nonprofit group funds a communication discussing an issue of concern to the group and urges whoever hears or reads the ad to contact a named public official to urge him or her to take some action consistent with the nonprofit's agenda, and in each, the public official is a candidate in the coming election. ${ }^{56}$ Thus, all the situations have numerous facts that

53 The Bipartisan Campaign Reform Act of 2002 (“BCRA”), 116 Stat. 81, enacted, and the McConnell Court upheld, regulation of communications funded by state parties or committees, that "support" or "oppose" candidates for federal office. See 2 U.S.C. $\S \S 431(20), 441 \mathrm{i}(\mathrm{b})$, (c); McConnell, supra note 39, at 170. It is uncertain whether the Supreme Court will in the future conclude that such communications are independent. See Miriam Galston, Emerging Constitutional Paradigms and Justifications for Campaign Finance Regulation: The Case of 527 Groups, 95 GEO. L.J. 1181, 1210-11 (2007) (discussing the relationship between such state funded communications and coordinated expenditures).

54 Express advocacy would necessarily be classified as campaign activity for federal tax law purposes, as would contributing money to or coordinating with a campaign.

55 See Rev. Rul. 2004-6, 2004-1 CuM. BuLL. 328.

56 For example, a candidate for Governor of a state may be asked to take a certain position regarding an imminent death penalty execution or a candidate for a legislature 
suggest, although they do not necessitate, that the organization sponsoring the ad is attempting to influence the outcome of the election by portraying a candidate for public office as in favor of or in opposition to the group's objectives.

At the same time, each situation described in the Revenue Ruling might also be interpreted as grassroots lobbying, which would not be considered campaign intervention under the Code. For example, the group urges the recipients of the communication to ask the official named to fund something the group cares about (local exports), to support or veto a legislative initiative, or to oppose capital punishment. Under the tax law rules elaborated by the Service, sponsoring lobbying messages of this kind is permitted to 501(c)(3) groups up to a certain limit and is permitted to a nonprofit exempt under other subsections without any limit as long as the subject of the lobbying is germane to the organization's mission. ${ }^{57}$

The 2004 Revenue Ruling outlines the types of facts and circumstances that will determine whether, on balance, the Service considers the nonprofits in each of the six situations to be engaged in campaign intervention or issue advocacy. For example, if the communication being questioned is part of a series of similar public messages sponsored by the organization over a period of time, including times not scheduled to coincide with an election, the pre-election message is more likely to be classified as grassroots lobbying and less likely to be considered campaign activity. ${ }^{58}$ Similarly, if the pre-election message is linked to a specific event occurring near the time of the election, the pre-election message is more likely to be considered grassroots lobbying, especially if the non-election event is outside the organization's control. For example, if an execution is scheduled to take place shortly before or after the election in that state and the organization's pre-election message deplores capital punishment and urges citizens to call Governor $\mathrm{X}$ and tell him to place a moratorium on executions because of racial unfairness in sentencing patterns, the message might be classified as grassroots lobbying, even if capital punishment was a wedge issue in the Governor's race in that state. ${ }^{59}$ These facts would not, however, prevent the

may be urged to vote for or against a legislative proposal. See Rev. Rul. 2004-6, supra note 55 , at 334 ,

57 Charities described in section 501(c) can lobby as long as the activity is not “substantial.” See I.R.C. § 501(c)(3); Treas. Reg. §§ 1.501(c)(3)-1(b)(3)(I), -1(c)(3)(ii). Nonprofits exempt under other subsections of section 501 can lobby without limit in furtherance of their exempt purposes. See Rev. Rul. 71-530, 1971-2 CuM. BuLL. 237; Rev. Rul. 67-187, 1967-1 CuM. Bull. 185; Rev. Rul. 61-177, 1961-2 CuM. BuLl. 117 (501(c)(6) groups).

58 See Rev. Rul. 2004-6, supra note 55, at 330 (Situation 1), 332 (Situation 5).

59 Contrast Rev. Rul. 2004-6, supra note 55, at 332 (Situation 5) (where an execution had been scheduled and the message was part of an series, the pre-election message was not campaign activity even though the candidate's position was identified as opposed to that of the organization) and id. (Situation 6) (where there was no external event scheduled and the message was not part of an series, the pre-election message was campaign activity). 
Service from finding that the organization sponsoring the message was engaged in campaign activity if the external event allegedly motivating the message was a bill in the state legislature, say, to end capital punishment and it could be shown that the sponsoring organization had influenced the date on which the vote in the legislature was scheduled to coincide with the election. Other facts possibly suggesting the existence of campaign activity would be mentioning in the ad that the official to be contacted supports or opposes the position favored by the nonprofit, ${ }^{60}$ even if the ad avoids stating whether he or she is, or is not, fit to hold that office.

The balancing method utilized by the Service in Revenue Ruling 2004-6 is identical to the method it has employed in the other Revenue Rulings discussing voter education and other types of activities that can be partisan or nonpartisan, depending upon the manner in which they are conducted. ${ }^{61}$ At bottom, it entails the exercise of judgment to identify significant facts, interpret them in light of the context in which they occur, and determine the weight to accord to each.

\section{B. The Campaign Finance Law Bright Line Approach}

Although a facts and circumstances test may seem a reasonable way to appreciate the complex character of an entity's election related activities, the probing and balancing method they serve contrasts sharply with the bright line rule approach favored by the Supreme Court in Buckley v. Valeo and subsequent decisions and reasserted by the plurality opinion in Wisconsin Right to Life. The Buckley Court originally enunciated the express advocacy bright line rule in response to its concern that the vague "for the purpose of influencing a federal election" language in campaign finance law would have the effect of chilling non-campaign speech, especially the discussion of ideas and candidates. ${ }^{62}$ The Buckley Court did not claim that all campaign related speech other than express advocacy was discussion of ideas and candidates. Rather, it noted that it could be difficult to distinguish core campaign speech (urging the public to vote for or defeat a candidate) from other forms of political speech and issue discussion. ${ }^{63}$ The express advocacy rule was a response to this dilemma since it created a bright line rule to differentiate regulated speech from speech not subject to campaign finance regulation. The electioneering communication provisions enacted in 2002 as part of the McCain-Feingold campaign finance reform were designed by Congress to add an additional, and important, category of campaign speech that should be funded with hard money and subject to

60 See Rev. Rul. 2004-6, supra note 55, at 330 (Situation 1), 332 (Situation 6). But see id. at 332 (Situation 5) and supra note 44.

61 See supra notes 23-24 and accompanying text; Rev. Rul. 2007-41, 2007-1 CuM. BuLL. 1421.

62 See Buckley, supra note 34, at 76-80.

63 See Buckley, supra note 34, at 78-79. 
FECA disclosure while respecting Buckley's preference for a bright line rule. In upholding the constitutionality of these provisions, the McConnell Court appears to have accepted the bright line rule approach as well. ${ }^{64}$ In ruling that regulation of electioneering communications was constitutional, the Court noted that there was no vagueness problem because the criteria listed in the definition were both "easily understood and objectively determinable." 65

In Wisconsin Right to Life, the Supreme Court rejected the electioneering communication provision, despite the fact that it created a bright line rule, because the provision could apply to more than express advocacy or its "functional equivalent."66 At the same time, the Court reiterated its commitment to a bright line standard, emphasizing that campaign finance provisions should not be applicable in a way that "opens the door to a trial" on every communication an organization contemplates funding or necessitate elaborate discovery. ${ }^{67}$ For the plurality Wisconsin Right to Life opinion, that meant rejecting the FEC's intent-and-effect test for classifying campaign ads, because the test would require examining the larger context within which political communications were designed and broadcast to determine if they should be funded with hard money. ${ }^{68}$ The opinion strengthened its "four-corners-ofthe-text" rule by asserting that, if evidence of the existence of campaign activity and evidence of issues advocacy are equal, "the tie goes to the speaker, not the censor."69 The practical effect of the WRTL analysis is to create a presumption that political speech that is not express advocacy must be deemed to be issue discussion or grassroots lobbying until proven otherwise, and to require the government to satisfy this burden of proof without utilizing evidence that a court would consider more than minimally contextual. ${ }^{70}$

The Citizens United decision left this part of Wisconsin Right to Life's doctrine intact. Thus, the method now employed by the IRS to determine whether a nonprofit organization has intervened in a political campaign is exactly the method the Court rejected in Wisconsin Right to Life, namely a facts and circumstances test

64 The McConnell Court also upheld the constitutionality of a more indeterminate support/oppose standard, but only with regard to state and local political parties. See McConnell, supra note 39, at 166-70.

65 McConnell, supra note 39, at 194.

66 WRTL, supra note 11, at 2665. The Court attributed the requirement that electioneering communications be express advocacy or its functional equivalent to the McConnell Court, id at 2655, although the four dissenting justices in WRTL, who were part of the majority in McConnell, were adamant that this interpretation was not the opinion of the McConnell Court. See id. at 2699.

67 WRTL, supra note 11, at 2665-66 (asserting that "it must entail minimal if any discovery”).

68 WRTL, supra note 11, at 2665-67.

69 WRTL, supra note 11, at 2669.

70 The plurality opinion did agree that some recourse to context would be valid under its interpretation of the constitutional constraints. See WRTL, supra note 11, at 2669. 
that entails taking into account the larger context in which a communication or other activity occurs. Additionally, in federal tax cases, the organization seeking to avoid violating the campaign prohibition has the burden of proof, whereas the effect of Wisconsin Right to Life's tie breaking rule is to place the burden of proof on the government, even as it restricts the government's access to arguably relevant information.

\section{JUDICIAL SCRUTINY: STRICT OR LIGHT}

First Amendment issues have arisen repeatedly in connection with tax law regulations. Judicial controversies involving a First Amendment challenge to the denial of tax exemption or tax deduction have developed a doctrine independent of First Amendment jurisprudence in other areas involving free speech. The level of scrutiny that courts employ in such cases depends upon whether, as a threshold matter, the court finds that the government has burdened the challenger's speech. As is described in what follows, in general, if there is no burden as a matter of law, the courts subject the government's actions to the rational relation test-the lightest form of judicial scrutiny in the freedom of speech area. If, on the other hand, the government's actions are seen as burdening the speech rights of the affected party, the courts use some form of heightened scrutiny to determine whether the government has subjected the affected party to an unconstitutional condition on the receipt of a governmental benefit.

\section{A. The Deferential Tax Law Approach}

The tax law First Amendment decisions are, in general, deferential to government restrictions on deductions or exemptions because the courts have repeatedly stated their reluctance to second guess lawmakers' determinations in the area of tax. As early as 1940, the Supreme Court asserted that a legislature's tax classifications have "a presumption of constitutionality."71 Because of this presumption, the "burden is on the one attacking the legislative arrangement to negative every conceivable basis which might support it."72 As a corollary, the Supreme Court's First Amendment jurisprudence in tax cases thus entails that in tax cases, "statutory classifications are valid if they bear a rational relation to a legitimate governmental purpose."

71 Madden v. Kentucky, 309 U.S. 83, 88 (1940) (cited in TWR, supra note 14, at 547). The Court noted that the government's discretion in tax classifications is even greater than it is in other fields. Id.

72 Madden, supra note 71, at 88.

73 TWR, supra note 14 , at 547 . There is some ambiguity in the statement, however, since the full sentence reads "Generally, statutory classifications are valid...," and, as is discussed in what follows, the Court will subject statutes to a higher level of scrutiny in 
If, however, tax classifications burden "the exercise of a fundamental right, such as freedom of speech, or employ a suspect classification, such as race," courts will employ "a higher level of scrutiny.",74 Further, courts will subject to "strict scrutiny" any affirmative burden that the government places on speech on the basis of its content. ${ }^{75}$ Judicial deference to legislative judgments in tax cases thus may be diminished in certain instances involving the First Amendment, although the level of scrutiny or deference has not always been clearly articulated. ${ }^{76}$ Importantly, tax statutes that selectively exempt, or fail to exempt, specific categories of speakers are not necessarily "constitutionally suspect," however. ${ }^{77}$ They only trigger heightened scrutiny if in addition they discriminate on the basis of content, run the risk of suppressing specific ideas or points of view, target the press, or target a "small group of speakers."

The seminal 1959 case, Cammarano v. United States, reveals how the Supreme Court determines whether the threshold condition for "a higher level of scrutiny" is present, i.e., whether a fundamental right has been burdened. In that decision, the Court upheld a provision of the Code that denied taxpayers an otherwise valid business expense deduction for the cost of lobbying. ${ }^{79}$ The taxpayers had argued that the Code provision denied them a business expense deduction because of their involvement in constitutionally protected First Amendment speech. In rejecting their claim, the Court countered that the taxpayers' exercise of free speech was not burdened by the denial of a deduction. Rather, according to the Court, the taxpayers were only being required to pay for their lobbying activities without a government subsidy. ${ }^{80}$ The denial of a subsidy for First Amendment activities, in other words, did not infringe on the exercise of a fundamental right. As a result, the application of

certain circumstances.

74 TWR, supra note 14, at 547. This might seem to imply that the lobbying restriction at issue in the case should have been reviewed with a higher level of scrutiny than the rational relation test since the restriction affects freedom of speech. However, later in the decision, the Court notes that when Congress fails to subsidize a fundamental right, it does not infringe that right. See id. at 549.

75 See, e.g., Leathers v. Medlock, 499 U.S. 439, 447 (1991); Grossjean v. US, 297 U.S. 244-47. See also infra notes 81-91 and accompanying text (on Speiser).

76 See the discussion in Am. Soc'y of Ass'n Executives v. U.S., 23 F. Supp. 2d 64, 6869 (D.D.C. 1998), affirmed, 195 F.3d 47 (1999).

77 Leathers v. Medlock, supra note 75, at 444. See also infra note 80 and accompanying text.

78 Leathers v. Medlock, supra note 75, at 447.

79 See Cammarano v. United States, 358 U.S. 498 (1959).

80 See Cammarano, supra note 79, at 513 (denying the taxpayers a deduction deprived them not of free speech, but of free speech at the government's expense). In his concurrence, Justice Douglas observed that the First Amendment would have been violated only if Congress had denied all deductions for ordinary and necessary expenses to a taxpayer who lobbied. Id. at 515. 
heightened scrutiny was not warranted. ${ }^{81}$

In Cammarano, the Supreme Court, in dicta, compared the policy underlying the ban on business deductions for lobbying expenses with the policy embodied in the provision of the tax law denying charitable tax exemption to otherwise qualified 501(c)(3) organizations if they engage in a substantial amount of lobbying. ${ }^{82}$ More than two decades later, in Taxation with Representation, the constitutionality of the limits on lobbying by charities was itself subject to a direct challenge. The Supreme Court reiterated the teaching of Cammarano that it is no infringement upon speech to deny it a subsidy, and it expanded Cammarano by stating that strict scrutiny would not be required even if Congress chose to provide a tax subsidy selectively, e.g., to some but not all categories of exempt organizations. ${ }^{83}$ As a result, the Court ruled against the public interest organization in the case, which had been denied 501(c)(3) charitable exemption because it proposed to lobby in excess of the statutory lobbying limit. $^{84}$ In both Cammarano and Taxation with Representation, the Supreme Court discussed the government's stated goal, that political "controversies ... must be conducted without public subvention; the Treasury stands aside from them." " In both cases, the Court emphasized that as a constitutional matter, "a legislature's decision not to subsidize the exercise of a fundamental right does not infringe the right." ${ }^{86}$ Thus, the government's goal of securing its own neutrality and a level playing field for those who lobby was subjected to a minimal burden of justification. ${ }^{87}$ As the Cammarano Court explained, "[s]ince purchased publicity can influence the fate of legislation which will affect, directly or indirectly, all in the community, everyone should stand on the same footing as far as the Treasury is concerned." 88

A tax classification, or a failure to subsidize a fundamental right, nonetheless may violate the Constitution if a legislature's action involves content discrimination or the intent to suppress certain ideas, as occurred in Speiser v. Randall. ${ }^{89}$ In that

81 See Cammarano, supra note 79.

82 See Cammarano, supra note 79, at 512.

83 See TWR, supra note 14, at 548. See also Rust v. Sullivan, 500 U.S. 173, 192 (1991); Leathers v Medlock, supra notes 75,at 73-74 and accompanying text.

84 See TWR, supra note 14. Under I.R.C. § 501(c)(3) and the associated regulations, an organization can engage only in an "insubstantial" amount of lobbying.

85 Cammarano, supra note 79, at 512 (citing Slee v. Commissioner, supra note 22, at 85).

86 TWR, supra note 14, at 549. See also Cammarano, supra note 79, at 535 (Douglas, J., concurring) (criticizing "the notion that First Amendment rights are somehow not fully realized unless they are subsidized by the State”).

87 See the discussion infra at

88 Cammarano, supra note 79, at 513.

89 TWR, supra note 14, at 548, citing Cammarano, supra note 79, at 513, which cited Speiser v. Randall, 357 U.S. 513, 519 (1958). See also Leathers v Medlock, supra note 75. In Speiser, the Court struck down statutory provision, itself based upon a provision 
case, a provision of the California Constitution and implementing legislation denied the State's veterans property tax exemption to any veteran who failed to sign a loyalty oath stating that the signatory did not advocate the violent overthrow of the government nor support a foreign nation at war with the United States. ${ }^{90}$ The exemption in question was sought by certain World War II veterans who had received honorable discharges and refused to sign the oath. ${ }^{91}$ The Supreme Court concluded that the constitutional provision should be interpreted to mean what the California Supreme Court said it meant, i.e., that it applied only to those who actually engaged in speech that would be criminally punishable under California criminal law and not to abstract advocacy. ${ }^{92}$ Thus construed, the loyalty oath was unconstitutional because it imposed on individuals failing to sign the oath an unreasonable condition, namely, the burden of proving they were not in violation of criminal law. ${ }^{93}$ This violated the applicants' due process rights because the state's reliance on a "short-cut" procedure (the oath) might well have the effect of infringing upon their free speech. ${ }^{94}$

The Speiser Court said explicitly that the loyalty oath required by California was "frankly aimed at the suppression of ideas." ${ }^{95}$ When such factual situations arise, a heightened form of scrutiny, i.e., more than the rational relation test, is required to determine if the regulation in question is constitutional. Subsequent tax law decisions have distinguished Speiser's holding when explaining why a particular governmental action is valid. ${ }^{96}$ These tax cases are consistent with, and sometimes cite, First Amendment cases in other areas of the law invalidating government discrimination based upon the content of speech or designed to suppress dangerous ideas. ${ }^{97}$

Tax cases involving speech restrictions in connection with deductions or

of the California constitution, that denied a property tax exemption to persons who did not sign a loyalty oath.

90 Speiser, supra note 89, at 515.

91 Speiser, supra note 89, at 514-15.

92 See Speiser, supra note 89, at 519-20.

93 See Speiser, supra note 89, at 523-24.

94 See Speiser, supra note 89, at 528-29. However, neither signing or failing to sign the oath was conclusive as to an applicant's entitlement to the exemption. See id. at 521 n.6.

95 Speiser, supra note 89, at 519.

96 See, e.g., Cammarano, supra note 79, at 513 (rejecting the plaintiffs' analogy to Speiser on the ground that there was no suppression of ideas in the tax statute); TWR, supra note 14, at 548, 550 (noting the outcome would be different if the tax provision involved "the suppression of dangerous ideas").

97 For example, Perry v. Sinderman, 408 U.S. 593, 598 (1972) (invalidating summary judgment for a state college that failed to renew a faculty member on the grounds that the nonrenewal may have been a result of the fact that the faculty member had criticized the school publicly, including before a legislative committee). See also FCC v. League of Women Voters, 468 U.S. 364, 383 (1984) (invalidating a regulation prohibiting nonprofit broadcast stations that were recipients of federal funds from editorializing, which, the Court said, was suppression of speech based upon content). 
exemptions are portrayed by the Supreme Court as a subset of cases involving a government subsidy or grant. ${ }^{98}$ In some non-tax subsidy cases, the Court's analysis is framed in terms of the nature and validity of the conditions the government has placed on the recipient, or potential recipient, of government funds. ${ }^{99}$ In general, these cases examine the type of government benefit involved, the character of the right affected by the condition imposed, the degree of the burden imposed by the condition, the importance of the government's reason for imposing the condition, and the relationship between the government's purpose and the means chosen to achieve it. ${ }^{100}$

Subsidy cases are not, however, necessarily analyzed within this framework. For example, in Rust $v$. Sullivan, the plaintiff organization challenged a speech restriction imposed upon the receipt of federal funds as an unconstitutional condition. ${ }^{101}$ In rejecting the claim that this was an unconstitutional condition case, the Court said

our "unconstitutional conditions" cases involve situations in which the Government has placed a condition on the recipient of the subsidy rather than on a particular program or service, thus effectively prohibiting the recipient from engaging in the protected conduct outside the scope of the federally funded program. ${ }^{102}$

98 See, e.g., TWR, supra note 14, at 544 (stating that "tax exemptions and tax deductibility are a form of subsidy that is administered through the tax system"). The Court's equation of deductions and exemptions with subsidies has been challenged by numerous commentators. See, e.g.,

99 See, e.g., Legal Services Corp. v. Velazquez, 531 U.S. 533 (2001).

100 On the doctrine of unconstitutional conditions as applied in exemption and deduction cases, see John Simon, Harvey Dale, and Laura Chisolm, The Federal Tax Treatment of Charitable Organizations, in THE NONPROFIT SECTOR: A RESEARCH HANDBOOK 267, 276 (Walter W. Powell \& Richard Steinberg, eds. 2006) (concluding thhat the area is sufficiently murky that accurate predictions are impossible). The literature discussing the doctrine of unconstitutional conditions in general is voluminous. Some of the classic articles are Daniel A. Farber, Another View of the Quagmire: Unconstitutional Conditions and Contract Theory, 33 FLA. ST. U. L. REV. 913 (2006); Frederick Schauer, A UNIFYING THEORY?: Too Hard: Unconstitutional Conditions and the Chimera of Constitutional Consistency, 72 DENV. U. L. REv. 989 (1995); Kathleen Sullivan, Unconstitutional Conditions, 102 HARV. L. Rev. 1415 (1989); Richard A. Epstein, The Supreme Court, 1987 Term-Foreword: Unconstitutional Conditions, State Power, and the Limits of Consent, 102 HARV. L. REV. 4 (1988). In the words of Steven Gey, "Virtually everyone agrees that the unconstitutional conditions doctrine is a mess." Contracting Away Rights: A Comment on Daniel Farber's “Another View of the Quagmire," 33 FlA. ST. U. L. REV. 953, 953 (2006).

101 Rust, supra note 83, at 192.

102 Rust, supra note 83, at 197. 
Rust involved Title $\mathrm{X}$ funding, and the speech restriction required recipients of Title $\mathrm{X}$ money to abstain from informing patients of abortion as a possible option for them to consider. The Court concluded nonetheless that grant recipients were not prevented from counseling about abortion because they were free to engage in such counseling using premises that were physically separate from the facility receiving Title $X$ funds. ${ }^{103}$ In support of its finding, the Court cited a passage in League of Women Voters to the effect that the speech restriction on government funding in that case would have been upheld if Congress had authorized the grant recipients to establish affiliated entities to engage in the restricted speech without federal funds. ${ }^{104}$ Thus, TWR, ${ }^{105}$ League of Women Voters, and Rust agree that if an alternate channel exists for speakers to engage in the type of speech restricted by a federal grant or subsidy, there is no burden (as a matter of law) ${ }^{106}$ and, a fortiori, no unconstitutional condition. ${ }^{107}$ Hence, the validity of the restriction must be justified employing only a rational basis test.

\section{B. The Heightened Scrutiny of Campaign Finance Law}

Outside the tax area, the Supreme Court has generally held that it will employ strict scrutiny or some other type of heightened scrutiny in cases involving restrictions on free speech. As was stated in Turner Broadcasting System, Inc. v. Federal Communications Commission, content based restrictions are subject to strict scrutiny and content neutral restrictions are evaluated by "intermediate scrutiny. ${ }^{108}$ These standards have been applied in a wide range of circumstances involving regulation of individuals, non-business associations, corporations, the press, and other types of media.

When campaign finance regulation is involved, however, the Supreme Court

103 Rust, supra note 83, at 197.

104 Rust, supra note 83, at 197, citing League of Women Voters, supra note 97, at 400, which cited TWR, supra note 14.

105 See infra notes 131-136 and accompanying text.

106 Courts will concede that there is an economic burden, but an economic burden does not imply the existence of a legal burden. See infra notes [149-50] and accompanying text.

107 Arguably Velazquez should be included in this list. In that case, the Court found that the absence of an alternative channel for indigent clients of federally subsidized legal services was an important factor leading it to invalidate the funding restriction imposed by Congress. See Velazquez, supra note 99, at 546-47. However, the Court also said that the restriction "suppressed speech inherent in the nature of the medium" (lawyering), id. at 543, and interfered with the judicial function, id. at 546. Thus, it is unclear how the Court would have ruled had there been an alternate channel for the plaintiff's clients.

108 See Turner Broadcasting System, Inc. v. FCC, 512 U.S. 622, 641-42 (1994)

(basing this observation upon earlier Supreme Court decisions). 
usually examines the regulations burdening speech using strict scrutiny. ${ }^{109}$ This standard typically entails determining whether restrictions on speech serve a compelling state interest and whether restrictions are narrowly tailored to further that interest. ${ }^{110}$ Starting with Buckley and continuing through Citizens United, the Supreme Court has maintained repeatedly and emphatically that the only compelling state interest justifying the regulation of campaign speech is the need to prevent corruption or the appearance of corruption. ${ }^{111}$ On several occasions, the Court has equated preventing influence over or access to elected officials with the compelling state interest in preventing corruption or its appearance. For example, in McConnell, the Court noted that campaign finance regulation is justified to "prevent access and influence from being bought or sold,"112 and in Federal Election Commission v. Colorado Republican Federal Campaign Committee, the Court affirmed its understanding that corruption means "not only ... quid pro quo agreements, but also ... undue influence on an officerholder's judgment, and the appearance of such influence." 113

In Austin v. Michigan State Chamber of Commerce, the Supreme Court enlarged the notion of corruption to include certain situations in which the members or shareholders of a corporation do not necessarily approve the political choices funded by

it, ${ }^{114}$ an idea first endorsed in dicta by the Court in Massachusetts Citizens for Life. ${ }^{115}$ In Citizens United, however, the Court repudiated this understanding of a compelling governmental purpose, expressly overruling Austin. ${ }^{116}$ In addition, the Court made

109 Usually, but not always. See infra notes 120-21 and accompanying text.

110 See WRTL, supra note 11, at 464; McConnell, supra note 39, at 115-16. Not all courts use the phrase "strict scrutiny." The Court in Buckley, for example, said that restrictions affecting the First Amendment must be examine with "exacting scrutiny." Buckley, supra note 34, at 64. This has usually been equated with strict scrutiny. See, e.g., McConnell, supra note 38, at 291 (Kennedy, J., dissenting in part and concurring in part). For a succinct statement of the strict scrutiny doctrine, with which he vehemently disagrees, see Eugene Volokh, Freedom of Speech, Permissible Tailoring and Transcending Strict Scrutiny, 144 U. PA. L. REV. 2417, 2418-24 (1997).

111 See Buckley, supra note 34, at 25-26; Citizens United, supra note 13, at *60 (describing the view of Buckley, with which the Court agreed). Note, however, that in Citizens United, the Court emphasized the purpose of ensuring the receipt of information rather than corruption. See supra note _ and accompanying text.

112 McConnell, supra note 39, at 154. See also FEC v. Nat'l Right to Work Comm., 459 U.S. 197, 210 (1982).

113 FEC v. Col. Republican Fed. Campaign Comm., 533 U.S. 431,441 (2001) (Colorado II).

114494 U.S. 652, 660 (1990); see also FEC v. Beaumont, 539 U.S. 146, 159, n. 5 (2003) (noting that);

115 See Massachusetts for Life, supra note 48, at 258 (asserting that "the power of the corporation may be no reflection of the power of its ideas").

116 See Citizens United, supra note 13, at *63-*79. 
clear its intention to limit the concept of corruption to quid pro quo corruption rather than access or influence, ${ }^{117}$ even though it also noted that several times in the past the Court had observed that campaign finance "restrictions on direct contributions are preventative, because few if any contributions to candidates will involve quid pro quo arrangements. ${ }^{118}$

Employing the corruption standard, the Supreme Court has struck down spending limits for candidates for Congress and state elections, limits on independent expenditures, a prohibition against corporate and union political advertisements on the eve of elections, various disclosure rules, a prohibition against certain advocacy organizations using their general corporate funds for campaign expenditures, and special financing rules for candidates running against high wealth, self-financed opponents. ${ }^{119}$ In Citizens United, the Court added to this list by concluding that the state interest in preventing corruption or its appearance was not sufficiently strong to justify denying corporations the ability to use business revenues to pursue their electoral objectives. ${ }^{120}$

On a few occasions, the Supreme Court has employed an intermediate level of scrutiny in campaign finance cases. In general, intermediate scrutiny permits the government to demonstrate something less than a compelling interest to justify the imposition of restrictions on speech, if the means chosen to further that interest are in fact designed in a proper manner. In First Amendment cases involving restrictions on speech, the Supreme Court has often stated that the test is satisfied if the restriction

furthers an important or substantial governmental interest; if the governmental interest is unrelated to the suppression of free expression; and if the incidental restriction on alleged First Amendment freedoms is no greater than is essential to the furtherance of that interest. ${ }^{121}$

The means chosen satisfy this "essential" standard if the government's interest "would be achieved less effectively absent the regulation."

In campaign finance cases, the Supreme Court appears to have used intermediate scrutiny when it evaluated the constitutionality of FECA's limitations on the amount of political contributions that could be made to candidates and parties. In

117 See Citizens United, supra note 13, at *83-*85.

118 See Citizens United, supra note 13, at *79. The Court indicated that preventive measures were necessary, even though quid pro quo transactions would fall under bribery laws, because of evidentiary problems. Id.

119 See Davis v. FEC., 554 U.S. _ 128 S. Ct. 2759 (2008); WRTL, supra note 11;

Randall v. Sorrell, 548 U.S. 230 (2006); Massachusetts Citizens for Life, supra note 48;

Buckley, supra note 34.

120 See Citiznes United, supra note 13.

121 United States v. O'Brien, 391 U.S. 367, 377 (1968).

122 Ward v. Rock Against Racism, 491 U.S. 781, 799 (1989). 
Buckley, the Court applied what it referred to as the "lesser demand" of regulations being "closely drawn" to match a "sufficiently important [government] interest." ${ }^{123}$ In connection with FECA's restrictions for public financing, the Buckley Court also compared the burden caused by these restrictions with the burden resulting from state law restrictions on ballot access. Although the latter were subject to "exacting scrutiny," the Court was less rigorous with the former because public financing is "generally less restrictive of access" than ballot restrictions. ${ }^{124}$ The Court did not expressly label its method "intermediate scrutiny" (or anything else), but it appears that it was using such scrutiny since it was using a form of heightened scrutiny and was clearly not using strict scrutiny.

In short, tax and campaign finance jurisprudence embody distinct and generally inconsistent principles regarding the appropriate form of judicial scrutiny to test the constitutionality of restrictions on speech. In the First Amendment tax cases, the courts gravitate toward the rational relation test because of the presumption of constitutionality, and heightened scrutiny is the exception. In contrast, in campaign finance cases, the presumption is that strict scrutiny applies, and a lesser form of heightened scrutiny is the exception. In the tax cases, it is permissible to discriminate on the basis of the identity of the speaker, whereas in campaign finance law it is not. In tax cases, the courts place the burden of proof on the party challenging a government restriction on speech, whereas in campaign finance law it is exactly the reverse. Finally, underlying the tax restrictions is the government's interest in equalizing access to government funding, whereas the campaign finance cases categorically reject equalizing speakers' resources as a valid government purpose for burdening speech in any way. As a result of these differences, tax law provisions that affect speech are far more likely to be upheld than are restrictions imposed by campaign finance law.

\section{TAX LAW FIRST AMENDMENT JURISPRUDENCE APPLIED}

Parts I-III gave an overview of the general principles of free speech doctrine in the areas of tax exemption and campaign finance. This Part applies the tax law principles to the restrictions prohibiting section 501(c)(3) groups from engaging in

123 See Nixon v. Shrink Missouri Gov't PAC, supra note 45, at 387-88; see also Buckley, supra note 34, at 16 (expenditure limits require "exacting scrutiny"), at 20, 2526 (because contribution limits involve "only a marginal restriction" on free speech, they are constitutional where they are "closely drawn" to further the weighty interests" of preventing corruption); WRTL, supra note 11, at 2664 (citing Buckley, supra note 34 , at $44-45$, and four later cases repeating the need for strict scrutiny whenever "political speech" is burdened).

124 See Buckley, supra note 34, at 94-96 (finding that such financing served "sufficiently important governmental interests and has not unfairly or unnecessarily burdened the political opportunity of any party or candidate"). 
political campaign activity.

\section{A. What Constitutes A Burden on Speech}

Tax exempt groups described in section 501(c)(3) of the Code must meet both affirmative and negative requirements. The affirmative requirement is that the group have as its purpose one or more public goods that the Code and regulations characterize generically as "charitable." These include helping the poor, sick, or disadvantaged; promoting education, religion, science, literature, and public safety; lessening the burdens of government; and otherwise improving social welfare. ${ }^{125}$ The negative requirements prohibit 501(c)(3) groups from benefiting any insider ("private inurement"), having even one substantial non-exempt purpose, engaging in more than insubstantial lobbying, and participating or otherwise intervening in an electoral campaign for public office. ${ }^{126}$

At first glance, based upon the traditional tax law constitutional jurisprudence discussed in Parts I-III, the absolute prohibition against 501(c)(3) organizations participating in electoral campaigns would seem not to violate the First Amendment. In a closely analogous situation, the Supreme Court in Taxation with Representation upheld the requirement that 501(c)(3) groups not engage in substantial lobbying. ${ }^{127}$ Cammarano v. United States, also discussed above, ${ }^{128}$ similarly upheld a prohibition on deducting the cost of lobbying that would otherwise have been an ordinary and necessary business expense. The foundation of both decisions was the doctrine that fundamental First Amendment rights are not burdened, as a matter of constitutional law, by being denied a tax benefit, since the First Amendment does not guaranty the right to exercise First Amendment freedoms at the government's expense. ${ }^{129}$ Because the right to lobby and the right to be involved in political campaigns are both core First Amendment values, ${ }^{130}$ the constitutional analysis should be the same in both areas.

Taxation with Representation, however, is arguably inapposite because the organization in that case was permitted to establish a sister 501(c)(4) organization that could lobby without limit, assuming that none of its funds were derived from the

125 See I.R.C. § 501(c)(3), Treas. Reg. § 1.501(c)(3)-1(d). The regulations additionally mention lessening "neighborhood tensions," prejudice, discrimination, community deterioration, and juvenile delinquency, and promoting human and civil rights. Id. at $11(\mathrm{~d})(2)$.

126 See I.R.C. § 501(c)(3); Treas. Reg. § 1.501(c)(3)-1(b)(1)(iii), (3), -1(c)(1), (3).

127 See supra notes 83-88and accompanying text.

128 See supra notes 79-82 and accompanying text.

129 See Cammarano, supra note 79, at 513; TWR, supra note 14, at 544.

130See Eastern Railroad Presidents Conf. v. Noerr Motor Freight, Inc., 365 U.S. 127, 137-138 (1961) (stating that lobbying is protected by the First Amendment), cited in TWR, supra note 14, at 552 (Blackmun, J., concurring). 
501(c)(3) group. ${ }^{131}$ Employing a sister organization this way would enable the 501(c)(3) group to conduct its non-lobbying activities (and insubstantial lobbying activities as well) using money subsidized by the charitable contribution deduction available to the group's donors, while its 501(c)(4) counterpart would lobby without funds thus favored. ${ }^{132}$ The 501(c)(3) group's ability to lobby using an affiliated organization was noted by the majority opinion, ${ }^{133}$ and it was pivotal to the conclusion of Justice Blackmun's concurrence that the taxpayer's speech rights had not been infringed. ${ }^{134}$

This structural arrangement, which became formalized as the alternative channel doctrine, is now considered to be crucial to the outcome in TWR. ${ }^{135}$ For the alternate channel to enable the 501(c)(3) group to lobby meaningfully, according to $T W R$, the group needed to be able to control an affiliated 501(c)(4) group's lobbying message. ${ }^{136}$ In the area of campaign activity, however, the existence of an alternate channel for campaign activities is less clear cut than it was for lobbying. Section 527 of the Code provides for "political organizations," which are exempt entities created and operated "to influence the selection, nomination, election, or appointment of one or more candidates for public office."137 Since a 501(c)(3) group is prohibited from creating an affiliated section 527 political organization to engage in campaign activities on its behalf, ${ }^{138}$ it seems to be denied the type of sister organization crucial to TWR's validation of the lobbying limitation.

Section 501(c)(3) organizations are, however, permitted to establish one or more sister 501(c)(4) groups, and the latter are permitted to participate in campaigns

131 See TWR, supra note 14, at 544 n..6. The Service also requires that the lobbying be in furtherance of the group's exempt purpose.

132 The 501(c)(4) group's exemption is still a subsidy, according to the Court, although the group would be less heavily subsidized than a 501(c)(3) organization, which could combine the benefit of exemption with that of receiving funds entitled to the charitable contribution deduction. See TWR, supra note 14, at 544 (stating that the exemption is the functional equivalent of a "cash grant"). [Buckles criticizes Tobin's reliance on this difference to justify political campaign activity on subsidy grounds.]

133 See TWR, supra note 14, at 545.

134 See TWR, supra note 14, at 552-53. The concurrence of Justice Blackmun was joined by Justices Brennan and Marshall.

135 The majority opinion did not emphasize the alternate channel for lobbying available to the plaintiff, but the concurrence considered it indispensable to the outcome in the case, and subsequent Supreme Court decisions have adopted the view of the concurrence. See FCC v. League of Women Voters, supra note 97,at 400 (1984); Rust v. Sullivan, supra note 83 , at 196 . Several appellate and district courts have similarly interpreted TWR. See Miriam Galston, Campaign Speech and Contextual Analysis, 6 FIRST AMEND. L. REV. 100, 113-17 (2007).

136 See TWR, supra note 14, at 553 (Blackmun, J., concurring).

137 See I.R.C. § 527(e)(1)-(2).

138 See S. ReP. No. 93-1357, at 30 (1974). 
as long as they remain primarily dedicated to their core social welfare mission. ${ }^{139}$ This limitation, coupled with the requirement that all activities not directed toward a 501(c)(4) group's social welfare mission must be aggregated to determine if the group retains its primary focus on its exempt purpose, ${ }^{140}$ creates an upper limit on the degree to which the sister organization can be involved in political campaigns. ${ }^{141}$ The opportunity for a 501(c)(3) organization to participate in campaigns through a sister 501(c)(4) group would be correspondingly circumscribed. Thus, the 501(c)(4) alternative channel for 501(c)(3) groups that wish to campaign may provide the 501(c)(3) groups with a less extensive alternative channel than was available to the plaintiffs in Taxation with Representation. At the same time, 501(c)(4) groups are themselves permitted to create affiliated section 527 political organizations. A 501(c)(3) group is thus permitted to have a sister 501(c)(4) organization that can engage in some campaign activity itself and can have an affiliated 527 organization devoted exclusively to participation in campaigns. ${ }^{142}$ Is this Rube Goldberg arrangement likely to satisfy the constitutional requirements of the alternate channel test?

No Supreme Court decision to date has addressed this question directly. ${ }^{143}$ The closest the Cammarano decision comes is the assertion, made by Justice Douglas in his concurrence, that he would consider the denial of a business deduction for lobbying expenses to be a penalty if Congress were to deny a taxpayer that lobbies all business deductions, and not just a deduction for lobbying expenses. ${ }^{144}$ For the majority in that case, the taxpayers' speech rights were not burdened merely because they had to pay for lobbying "out of their own pockets." ${ }^{145}$ The majority opinion in Taxation with Representation struck the same note as Justice Douglas, observing that TWR was not being denied a charitable contribution deduction for its non-lobbying activities. ${ }^{146}$ Although it noted that there was some burden involved in setting up a 501(c)(4) group, ${ }^{147}$ the majority concluded nonetheless that Congress had not

139 See supra notes 22-25 and accompanying text.

140 See supra note 24.

141 The 501(c)(4) group may be taxed, using its campaign expenditures as the tax base, depending upon whether it has net investment income. See I.R.C. § 527(f)(1). If the tax under this section would be large, this tax exposure might further restrain the sister organization's campaign activities.

142 See Kindell \& Reilly, supra note 28, at 477-78.

143 Precisely this issue was under review in Branch Ministries, supra note 14, however, and the Court of Appeals for the District of Columbia Circuit held that the political prohibition was constitutional, inter alia, because the plaintiff could establish a 501(c)(4) group that could set up an affiliated PAC. 211 F.3d, at 143-44.

144 See Cammarano, supra note 79, at 515 (Douglas, J., concurring).

145 Cammarano, supra note 79, at 513.

146 See TWR, supra note 14, at 545.

147 See TWR, supra note 14, at 544 n.6. 
infringed any First Amendment rights or regulated any First Amendment activity."148

These two cases thus suggest that the Supreme Court will be quite deferential to Congress when assessing the threshold issue, i.e., whether speech has been burdened as a matter of constitutional law. They imply that an organization's speech rights would be infringed only if it was prevented from engaging in First Amendment activity absolutely as a condition of receiving the tax exemption to which it was otherwise entitled. ${ }^{149}$ However, as noted above, ${ }^{150}$ the Taxation with Representation decision has been interpreted by later cases to say that the taxpayer's speech rights would be infringed if there were no alternate channel for the exercise of those rights. ${ }^{151}$ Cammarano and Taxation with Representation (as interpreted by later cases) thus may advance different accounts of what constitutes a burden on political speech. Further, Taxation with Representation's less deferential approach sheds little light on the type of affiliation that will satisfy the alternate channel test beyond its assertion that the exempt organization must be able to control the content of the affiliated organization's lobbying speech. By themselves, then, these cases do not definitively answer the "Rube Goldberg" question.

A recent decision suggests, although it does not guaranty, that the Supreme Court would not find that the current campaign prohibition for 501(c)(3) organizations an infringement on the organizations' free speech. Ysursa v. Pocatello Education Association involved a challenge to an Idaho law prohibiting any public employer (state or local) from providing a payroll deduction for employees' payments to their union's PAC. ${ }^{152}$ The District Court concluded that Idaho's refusal to provide a payroll deduction for political contributions for state employees was not an “abridgement of the unions' speech" because Idaho was under no obligation to incur the cost of such a program. ${ }^{153}$ However, it found the State's ban on local governments providing such a payroll deduction unconstitutional because no state subsidy was involved at the local level. ${ }^{154}$ Only the latter ruling was appealed to the Court of Appeals, which upheld the decision of the lower court. ${ }^{155}$

The Supreme Court reversed. Although the constitutionality of the prohibition as it affected the state government was no longer being challenged, the Court nonetheless reviewed the issue and repeated the lower court's reasoning that Idaho was under no obligation to "enhance" unions' political speech nor "aid" them in their political activities" by means of a payroll deduction. ${ }^{156}$ The Court supplemented the

148 TWR, supra note 14 , at 546.

149 See League of Women Voters, supra note 97, at 395.

150 See supra p. 25.

151 See supra notes 135-36 and the accompanying text.

152 See Ysursa v. Pocatello Education Ass’n, 555 U.S. __, 129 S. Ct. 1093 (2009).

153 See Ysursa, supra note 152, at 1097.

154 Ysursa, supra note 152, at 1097.

155 Ysursa, supra note 152, at 1097.

156 Ysursa, supra note 152, at 1098. 
lower court's reasoning by noting that Idaho had an "interest in avoiding the reality or appearance of government favoritism or entanglement with partisan politics.”157 The Court then used the latter rationale to justify the State's ban on local governments providing a payroll deduction for contributions to a union PAC, even though local government payroll deductions cost Idaho nothing and, according to the unions, could not be considered a "subsidy" by the State. ${ }^{158}$

In Ysursa, the Supreme Court accepted as fact that "unions face substantial difficulties in collecting funds for political speech without using payroll deductions." ${ }^{\text {159 }}$ Despite this finding, the Court asserted that there was no infringement on the unions' political speech and, thus, that the Idaho law should be reviewed using the rational basis test. ${ }^{160}$ To support its position, the Court repeatedly cited Taxation with Representation, which had also concluded that the economic burden caused by its decision was not of constitutional significance. The Court in that case argued that

[a]lthough TWR does not have as much money as it wants, and thus cannot exercise its freedom of speech as much as it would like, the Constitution does not confer an entitlement to such funds as may be necessary to realize all the advantages of that freedom. ${ }^{161}$

These two decisions involving free speech reach the same outcome as the Supreme Court's rulings in connection with the free exercise prong of the First Amendment, namely, that an organization's loss of revenue as a result of revocation of its exemption "is not constitutionally significant."162

The reasoning in Massachusetts Citizens for Life is consistent with these precedents. The Supreme Court in Massachusetts Citizens for Life invalidated a campaign finance law that required a corporate section 501(c)(4) group to fund certain of its campaign activities by using an affiliated political action committee (PAC) largely because of the administrative burden and related costs that the 501(c)(4) group would thereby experience. ${ }^{163}$ Although on the surface the Court's decision seems inconsistent with the alternate channel reasoning in Taxation with Representation, in point of fact the Court in Massachusetts Citizens for Life went out of its way to distinguish Taxation with Representation on the ground that the alternate channel

157 Ysursa, supra note 152, at 1098.

158 Ysursa, supra note 152, at 1101.

159 Ysursa, supra note 152, at 1098.

160 See Ysursa, supra note 152, at 1098.

161 TWR, supra note 14 , at 549 .

162 Jimmy Swaggart Ministries v. Board of Equalization, 493 U.S. 378, 391-92 (1990). See Hernandez v. Comm'r, 490 U.S. 680, 700 (1989). See also Branch Ministries, supra note 14, at 142 (citing these two Supreme Court decisions to justify upholding the political prohibition for 501(c)(3) organizations).

163 MCFL, supra note 48. 
procedure "would infringe no protected activity, for there is no right to have speech subsidized by the Government."164 Massachusetts Citizens for Life, in contrast, involved a direct restriction on the campaign activity of a nonprofit.

The Supreme Court's reliance in Ysursa was exclusively on the majority opinion in Taxation with Representation, which, as was noted earlier, ${ }^{165}$ appears more deferential to Congress than was Blackmun's concurrence. In short, Ysursa suggests that the Roberts' Court may be as willing as most previous Supreme Courts to find political speech unburdened as a constitutional matter when the effect of legislation denying an organization a tax favored status is to place it in a more burdensome economic position.

At least two appellate courts have issued similar rulings. In American Society for Association Executives v. United States, the Court of Appeals for the District of Columbia Circuit said that the rational relation test applied to section162(e)'s denial of business deductions for lobbying expenses, despite the provision's potential economic impact on 501(c)(6) organizations and their members, because they were free to avoid the problems complained of by setting up two 501(c)(6) organizations, one of which would not lobby at all. ${ }^{166}$ Citing Taxation with Representation, the court continued, "If this option is available, the treatment of lobbying contested here is subject only to 'rational basis' scrutiny, and, as we shall see, handily survives."167 Similarly, in Mobile Republican Assembly v. United States, the Court of Appeals for the Eleventh Circuit upheld the constitutionality of a disclosure provision for section 527 political organizations. ${ }^{168}$ Citing Taxation with Representation, the Eleventh Circuit said that, " $[t] h e$ fact that the organization might then engage in somewhat less speech because of stricter financial constraints does not create a constitutionally mandated right to the tax subsidy."169

Based upon the reasoning in the preceding Supreme Court and appellate court decisions, the current tax law prohibition on 501(c)(3) groups participating in political campaigns is likely to be understood as creating an economic burden on the groups' election related speech that does not create a corresponding constitutional burden.

The prohibition against campaign activity by charities might still be unconstitutional if it were seen as involving content discrimination by virtue of targeting "political" speech. A challenge of this kind is unlikely to succeed,

164 MCFL, supra note 48 , at 545-46.

165 Supra note 135 and page 27.

166195 F.3d 47 (D.C. Cir. 1999).

167 American Soc'y of Ass'n Execs., supra note 166, at 50.

168353 F.3d 1357 (11 ${ }^{\text {th }}$ Cir. 2003)

169 Mobile Republican Assembly, supra note 168, at 1361. The court also said that it was following $T W R$, in which the Supreme Court "analyzed the [unconstitutional] condition within the context of the overall tax scheme, rather than as a separate provision or penalty" in response to TWR's claim that the lobbying restriction was an unconstitutional condition. Id. 
however. In Cammarano, the Supreme Court rejected the charge that the denial of a business deduction for the cost of lobbying was content based because it targeted lobbying, asserting instead that the provision in question was a "nondiscriminatory denial of a deduction" that was clearly not part of an attempt to suppress specific ideas. $^{170}$ The Ysursa Court similarly rejected the claim that the Idaho statute prohibiting payroll deductions for contributions to union PACs was content based because of its impact on political speech. ${ }^{171}$

In sum, the threshold inquiry unto the existence of a burden resulting from the tax law's political prohibition is likely to conclude that no such burden exists because 501(c)(3) groups have a significant alternate channel for their campaign activities, economic burdens do not necessarily constitute legal burdens as a matter of constitutional law, and restrictions targeting campaign speech are not considered content discrimination.

\section{B. The Political Prohibition Scrutinized}

Based upon the preceding, the tax law prohibition should be reviewed using the rational relation test. This test is satisfied if government action is directed toward a legitimate government interest and the means chosen is rationally related to that goal. ${ }^{172}$

The legislative history is silent as to the reason the political prohibition was enacted in $1954 .{ }^{173}$ Prior to that time, the IRS had taken the position that political groups were subject to tax, there were judicial decisions supporting that position, and limitations on campaign activity had been proposed in Congress, but not enacted. ${ }^{174}$ These precedents are consistent with the goal of preventing charities from funding campaign activity with deductible charitable contributions. ${ }^{175}$ To the extent that this

170 Cammarano, supra note 79, at 513.

171 See Ysursa, supra note 152, at 1099. It is difficult to imagine what would constitute a content based denial of funding by a court that rejected such a charge in connection with the federal government's refuse to allow Title X funds to be used for abortion counseling or even counseling that mentioned abortion. See Rust v. Sullivan, supra note 83 , at 192-93. Of course, the dissent disagreed with the majority on this point. See id. at 209.

172 TWR, supra note 14 , at 547 .

173 See supra note 21.

174 See William P. Streng. The Federal Tax Treatment of Political Contributions and Political Organizations, 29 TAX LAWYER 139, 142-43 (1976). Initially, the IRS took the opposite position, however. See id. at 141.

175 In general, the rational relation test does not require the government to show that it in fact pursued a legitimate public purpose. See U.S. Railroad Retirement v. Fritz, 449 U.S. 166, 179 (1980):

Where, as here, there are plausible reasons for Congress' action, our inquiry is at an end. It is, of course, "constitutionally irrelevant whether this reasoning in 
is the goal of the political prohibition, the means chosen are reasonably related to the end, although they may not be the least restrictive means of achieving that objective. ${ }^{176}$ Current tax law, however, does more than prevent charitable contributions from being used to support campaign activities. ${ }^{177}$ Because of this, Professor Benjamin Leff has recently argued that the 501(c)(3) political prohibition could be unconstitutional "to the degree it goes beyond advancing a concern with expenditure equity." ${ }^{178}$ However, Leff also cautions that a mechanism used to allocate the cost of campaign activity to an affiliated entity would have to take into account hidden costs, such as some portion of the expense of developing and maintaining the 501 (c)(3) group's credibility, in order to be completely accurate. ${ }^{179}$

A second possible rationale, one advanced by the Ysursa Court, is the government's interest in not supporting or becoming entangled with partisan activities. ${ }^{180}$ This rationale does not seem applicable in relation to exempt organizations, however, because the Code in fact prohibits political intervention only in connection with 501(c)(3) groups, whereas other organizations exempt under 501(a) are not included in the ban. ${ }^{181}$ Indeed, Congress enacted section 527 to provide exempt status for the income of political organizations and to favor donors to such organizations by removing the their gift taxation exposure for large

fact underlay the legislative decision," Flemming v. Nestor, 363 U.S., at 612, because this Court has never insisted that a legislative body articulate its reasons for enacting a statute. This is particularly true where the legislature must necessarily engage in a process of line-drawing. The "task of classifying persons for . . . benefits ... inevitably requires that some persons who have an almost equally strong claim to favored treatment be placed on different sides of the line," Mathews v. Diaz, 426 U.S. 67, 83-84 (1976), and the fact the line might have been drawn differently at some points is a matter for legislative, rather than judicial, consideration.

I could not find an example of this reasoning in a Supreme Court case involving free speech or another fundamental right.

176 The fact that certain veterans' groups can engage in political campaigns, yet receive deductible contributions, does not undermine the rationality of the decision to prevent charities from intervening in campaigns. The Supreme Court has several times made the point, in connection with subsidies, that the government is free to provide subsidies selectively to achieve purposes it deems beneficial. See supra notes [76, 81].

177 See infra notes 183-87.

178 Benjamin M. Leff, "Sit Down and Count the Cost": A Framework for Constitutionally Enforcing the 501 (c)(3) Campaign Intervention Ban, 28 VA. TAX REV. 673, 686 (2009). See also Chris Kemmitt, RFRA, Churches, and the IRS: Reconsidering the Legal Boundaries of Church Activity in the Political Sphere, 43 HARV. J. ON LEGIS. 145 (2006) (arguing that under the Religious Freedom Restoration Act (RFRA), churches should be permitted to engage in political campaign activity as long as they do not use contributions tax deductible under section 170 of the Code).

179 See Leff, supra note 178, at 708-14

180 See supra notes [117-18] and accompanying text.

181 See supra notes 17-25 and accompanying text. 
contributions. ${ }^{182}$ Thus, existing tax law does not seem to reveal concern with governmental neutrality toward campaign activity.

The legislative history of section 527 political organizations, which specifically denies 501 (c)(3) groups the ability to establish a 527 group, ${ }^{183}$ suggests another possible rationale underlying the prohibition. Congress could easily have authorized 501(c)(3) groups to establish affiliated 527 groups subject to restrictions precluding the former

groups from funding the latter groups with funds derived from deductible contributions, but it chose not to. This raises the possibility that preventing political activities from being funded with deductible contributions was not the exclusive rationale for preventing 501(c)(3) groups from political intervention. The twin prohibitions against campaign intervention and establishment of a 527 group may reflect a belief that charitable exemption and partisan politics are incompatible.

The last explanation is consistent with the fact that the rationale for exempting 501(c)(3) groups from federal income tax and for allowing contributors to them a charitable contribution deduction in the first place is to encourage the existence and viability of associations dedicated to particular public purposes enumerated in the Code and elaborated in the Treasury regulations. ${ }^{184}$ Section 501 of the Code is not a federal version of state nonprofit laws, which permit entities to organize as nonprofit organizations as long as they do not distribute their revenues and are not established for a pecuniary purpose. Rather, section 501(c) targets specific categories of public purpose that lawmakers have determined should be encouraged through a system of tax exemption and, in some instances, charitable contribution deduction. ${ }^{185}$ This would appear to be precisely the type of project selection that the Supreme Court has approved in the past in public funding cases. ${ }^{186}$

182 See I.R.C. § 527.

183 See supra note 135.

184 See supra notes $122-23$ and the accompanying text.

185 It is possible to view section 501(c)(4) as describing any nonprofit organization with a public purpose that doesn't fit into other subsections of section 501(c). See JAMES J. Fishman \& StePHeN SCHWARZ, NONPROFIT ORGANIZATIONS: CASES AND MATERIALS 990 (2006) (asserting that "[a]s a practical matter...§ 501(c)(4) has become the default choice ("dumping ground"?) for organizations that fail to make the grade" as charities). While it is true that the meaning of "social welfare" in section 501(c)(4) is broad, not every nonprofit group that seeks 501(c)(4) status succeeds. See, e.g., Contracting Plumbers Co-op. Restoration Corp. v. United States, 488 F.2d 684, 686-87 (2d Cir. 1973); Rev. Rul. 77-273, 1977-2 CuM. Bull. 194; Rev. Rul. 61-158, 1961-2 CuM. Bull. 115. See also John Francis Reilly, Carter C. Hull, and Barbara A. Braig Allen, IRC 501(c)(4) Organizations, EXEMPT ORganizATIONS TECHNICAL InSTRUCtion Program FOR FY 2003, I-1, I-9 to I-12; Miriam Galston, Vision Service Plan v. U.S., Implications for the Campaign Activities of 501(c)(4) Groups, 53 EXEMPT ORG. TAX ReV. 165 (August 2006).

186 See Rust v Sullivan, supra note 83, at 193-95; League of Woman Voters, supra note 97, at 399-400. See also TWR, supra note 14, at 547-48 (rejecting the 
The prohibition against political intervention also can be justified as a corollary of the meaning of public purpose. Pursuit of a public purpose is not consistent with involvement in political campaigns, which is by definition partisan. The Service does not, for example, bar 501(c)(3) organizations from campaign activity that is nonpartisan, such as voter mobilization not favoring a specific political party or candidate. Nor, as described above, does it prohibit other election related activities that are conducted on a nonpartisan basis. ${ }^{187}$ As explained by the IRS, in contrast to lobbying, which can be targeted to specific legislation of direct interest to an organization, "support of a candidate for public office necessarily involves the organization in the total political attitudes and positions of the candidate.”188

Clearly, some exempt organizations are convinced that they can further their exempt purpose more effectively by supporting or opposing particular candidates for public office than without such actions, and they may be correct in some instances. However, as long as Congress's decision not to commit public funds to partisan methods of achieving public purposes bestows or withholds exemption in a politically neutral fashion, it would appear to meet the minimal requirements of the rational relation test without difficulty.

\section{Vagueness and Overbreadth Analysis}

The prohibition against political campaign activity could also be challenged as unconstitutionally vague or overbroad because neither the statute nor the regulations elaborate with precision the nature of the proscribed activity. ${ }^{189}$ The very general standards set forth in the statute and regulations are developed in a few judicial decisions, numerous Revenue Rulings, private letter rulings, and assorted other administrative pronouncements. Of course, letter rulings and similar administrative materials are not precedential guidance, which might affect a First Amendment challenge based upon vagueness or overbreadth since they cannot be cited in a judicial proceeding as precedent. ${ }^{190}$ There is some authority that a court can consult such materials for an indication of the IRS's interpretation of a tax provision ${ }^{191}$ and

organization's equal protection challenge on the ground that the substantial lobbying provision was part of Congress's legitimate tax classification function).

187 See supra notes 28-31 and accompanying text.

188 Gen. Couns. Mem. 34233, Dec. 3, 1969, at Lexis page 8.

189 See supra notes 13-15 and accompanying text. For the "analytical link" uniting vagueness and overbreadth analysis, see Kolender v Lawson, 461 U.S. 352, 358-359 (1983), cited in Nationalist Movement v. Comm'r, supra note 24, at 585. Nationalist Movement also cites LAWRENCE TRIBE, Constitutional LAW § 12-31 (2d ed. 1988) and Richard Fallon, Making Sense of Overbreadth, 100 YALE L.J. 853, 903-907 (1991). 190 See I.R.C. § 6110(k)(3); Treas. Reg. 601.201(l)(6).

191 See Fla. Power \& Light v. U.S., 56 Fed. Cl. 328, 334 (2003), citing Hannover 
even "accept the reasoning" as persuasive in the absence of authority to the contrary. ${ }^{192}$ Nonetheless, the courts are agreed that taxpayers are not entitled to have a court resolve a controversy based upon views expressed by the Service to other taxpayers or contained in internal administrative documents. ${ }^{193}$

Efforts to determine whether legislation is unconstitutionally vague often begin with a general statement of the public policies served by the vagueness standard. First and foremost is the concern that, absent sufficient specificity, government directives will fail to afford adequate notice to those affected concerning conduct required or prohibited. Frequently cited in this connection is the warning of Connally v. General Construction Co., that a criminal statute is unconstitutionally vague if "men of common intelligence must necessarily guess at its meaning and differ as to its application." 194 The opinion rested on the observation that due process presupposes that substantial fines and long terms of imprisonment may only be imposed if the nature of the proscribed conduct has been conveyed sufficiently to those potentially affected. ${ }^{195}$ Equally important is the

concern that a vague statute lends itself to arbitrary enforcement. ${ }^{196}$ Initially, most of the cases citing Connally, involved criminal statutes and loyalty oaths. ${ }^{197}$ More recently, the Connally pronouncement has been cited in the context of civil laws challenged for being unconstitutionally vague. ${ }^{198}$ However, "where a statute imposes criminal penalties, the standard of certainty is higher" than in other cases. ${ }^{199}$

It is unclear how these authorities would be applied in tax cases involving First Amendment issues and what level of scrutiny would be employed in analyzing the political campaign prohibition employing a vagueness or overbreadth test. Taxation with Representation is not useful here, since the plaintiff association did not "challenge the proscription against 'substantial lobbying' on grounds of

Bank v. Commissioner, 369 U.S. 672 (1962).

192 See AT\&T Corp. v. U.S., 63 Fed. Cl. 209, 213 (2004).

193 See Fla. Power \& Light, supra note 190, at 334.

194269 U.S. 385, 391 (1926), citing International Harvester Co. v. Kentucky, 234

U.S. 216, 221 (1914), which invalidated a criminal antitrust statute, and Collins v. Kentucky, 234 U.S. 634, 638 (1914), which invalidated a criminal statute prohibiting members of certain agricultural pools from acting independently of the pool.

195 Connally, supra note 194, at 390.

196 Kolender, supra note 189, at 358; Cramp v. Board of Public Instruction of Orange County, 368 U.S. 278, 283 (1961) (invalidating a loyalty oath that was punishable by dismissal from public employment and conviction for perjury).

197 See, e.g., supra note [183] and Speiser, supra note 89.

198 See, e.g., Big Mama Rag, supra note 15, at 1035.

199 Kolender, supra note 189 at 358 n.8 (citing Winters v. New York, 333 U.S. 507, 515 (1948)). See NEA v. Finley, 524 U.S. 569, 588 (1998) (observing that vagueness in a" criminal statute or regulatory scheme" could raise concerns not present when selecting recipients for publicly funded (NEA) grants). 
vagueness. ${ }^{200}$ In National Endowment for the Arts v. Finley, a public funding case decided in 1998, the Supreme Court upheld statutory criteria that had been challenged as both discriminatory and vague. ${ }^{201}$ In its decision, the Court distinguished the level of scrutiny required for criminal statutes and statutes that directly regulate conduct, on the one hand, and statutes involving subsidies, on the other. ${ }^{202}$ It held that "when the Government is acting as a patron rather than a sovereign," a level of imprecision is permitted that would be constitutionally unacceptable in other contexts. ${ }^{203}$

The campaign prohibition in the Code is clearly not a criminal statute since the sanctions for violating it range from a warning letter ${ }^{204}$ or the imposition of an excise $\operatorname{tax}^{205}$ to revocation of tax exemption. ${ }^{206}$ Although tax statutes are not necessarily regulatory statutes, it would seem that the campaign prohibition could be characterized as regulatory since its purpose is to control behavior rather than raise revenue. Alternatively, the prohibition can be seen as incidental to the statute's primary purpose of defining what is charitable by excluding activities that are private and partisan in nature. ${ }^{207}$ So interpreted the prohibition is less regulatory than classificatory, and the classification serves the government's interest in selecting as charities those nonprofits most worthy of public subsidy. The classification of the political prohibition as regulatory or not might well determine whether the challenge to it on vagueness grounds would be tested under a deferential standard or a form of heightened scrutiny.

One of the most careful analyses of vagueness in a section 501(c)(3) context occurs in Big Mama Rag v. United States. ${ }^{208}$ The Court of Appeals for the District of Columbia Circuit characterized the standard to be applied in First Amendment cases as "strict," regulations was unconstitutionally vague and prone to selective enforcement. ${ }^{210}$ The court found that the regulations' "full and fair" standard was not only too general to be informative; it noted as well that the regulations' reliance on "the reactions of

200 See Taxation with Representation of Washington v. Regan, 676 F2d 715, 726 n.22 (D.C. Cir. 1982).

201 See NEA v. Finley, supra note 199 (upholding admittedly vague and subjective standards for selecting recipients for NEA awards).

202 See NEA v. Finley, supra note 199, at 567-88.

203 See NEA v. Finley, supra note 199, at 588-89.

204 See IRS, Final Report, Project 302, Political Activities Compliance INITIATIVE ("PACI"). The Service found that 68 percent of the charities it investigated had in fact violated the political prohibition. Almost all these groups were issued "written advisories."

205 See I.R.C. $\S 4955$.

206 See I.R.C. § 501(c)(3), Treas. Reg. § 1.501(c)(3)-1(c)(3)(I), (iii).

207 See supra notes 182-85 and accompanying text.

208 Supra note 15.

209 Big Mama Rag, supra note 15, at 1035.

210 See Big Mama Rag, supra note 15, at 1037. 
members of the public" insured that the test would employ a "necessarily varying and unascertainable standard." ${ }^{211}$ Moreover, the applicable regulations were so confusing that it was unclear to the court whether the organization in question should have been subjected to the standard in the first place. ${ }^{212}$ The standard thus invited "subjective definitions." 213 And in fact, the court observed, these ambiguities had enabled the Service to apply the "full and fair" test to "only a very few organizations, whose views are not in the mainstream of political thought." ${ }^{214}$ In particular, the IRS appeared to have applied its test to a homosexual organization inappropriately, ${ }^{215}$ and the association involved in Big Mama Rag characterized itself as feminist and lesbian. $^{216}$

It seems, then, that the sub-text of the vagueness discussion in Big Mama Rag was the court's concern that the IRS was using the regulations' malleable standards to suppress certain kinds of ideas it found distasteful or contrary to public policy. ${ }^{217}$ This possibility is reinforced by the fact that, in developing its view of the strict standard to be applied to vagueness challenges in the First Amendment area, the Big Mama Rag court relied on cases that involved content discrimination and the suppression of viewpoints. ${ }^{218}$ That the Big Mama Rag outcome was driven by the court's response to the Service's practice of disfavoring views with which it did not agree substantively was also the interpretation of Big Mama Rag adopted by the Tax Court in a subsequent case that upheld the constitutionality of Revenue Procedure 86$43,{ }^{219}$ the ruling promulgated by the Service to supplement the definition of "education" in its regulations after they were declared unconstitutionally vague in Big Mama Rag. ${ }^{220}$

211 Big Mama Rag, supra note 15, at 1037.

212 Big Mama Rag, supra note 15, at 1036-37.

213 Big Mama Rag, supra note 15, at 1035.

214 Big Mama Rag, supra note 15, at 1036-37.

215 Big Mama Rag, supra note 15, at 1035. See also id. at 1040 (referring to the lower court's "value laden conclusion that Big Mama Rag was too doctrinaire").

216 Big Mama Rag, supra note 15, at 1032; Big Mama Rag v. United States, 494 F. Supp. 473, 480 (1979).

217 Of course, it is constitutional to deny 501(c)(3) exemption to a group that violates a strong public policy. See Bob Jones University v. U.S., 461 U.S. 574 (1983) (upholding the Service's denial of a charitable exemption to an institution of higher learning that discriminated in admissions on the basis of race).

218 See Big Mama Rag, supra note 15, at 1035.

219 1986-2 CuM. BuLL. 729.

220 See Nationalist Movement v. Comm'r, supra note 24, at 581-83. Rev. Proc. 86-43 was before the District Court for the District of Columbia Circuit in National Alliance v. United States, 710 F.2d 868 (D.C. Cir. 1983). The court in that case declined to rule directly on the constitutionality of the Revenue Procedure, but it did note (in dictum) that the four-part test went a long way toward "reducing" the vagueness in the "full and fair" test. Id. at 875 . 
Clearly, on its face, the political campaign prohibition is not designed to suppress specific viewpoints since it is not targeted to any political party or political orientation. However, it is possible to view the standard as not precise enough to afford notice to taxpayers attempting to comply with its strictures nor to prevent arbitrary, viewpoint based enforcement. Opinions are likely to differ as to the existence of political bias on the part of the IRS when it actually enforces the political prohibition. Complaints alleging biased enforcement have in fact been leveled against the agency. ${ }^{221}$ Responding to such complaints, the Treasury Inspector General of Tax Administration (TIGTA) conducted an investigation and gave the IRS a clean bill of health in $2005 .{ }^{222}$ In addition, since 2004, the IRS has established a national, standardized procedure for identifying and reviewing possible violations of the political prohibition in each election cycle. This procedure is known as the "Political Activities Compliance Initiative," or "PACI."223 The method employed, which is published on the IRS website, involves a specially trained team of personnel that reviews all of the referrals, decides which cases should be investigated, forwards them to designated agents in the field for investigation, and recommends sanctions when violations are found. ${ }^{224}$ Although these procedures do not guarantee lack of bias, the process should reduce the opportunity for viewpoint discrimination significantly because it is well documented and transparent.

Even if the IRS procedure is not seen to pose a substantial threat of bias, it is nonetheless possible that vagueness and overbreadth claims against the political

221 See, e.g., Branch Ministries, Inc. v. Rossotti, 40 F. Supp. 2d 15, 19 (D.D.C. 1999); Donald B. Tobin, The Law of Politics: The Role of Law in Advancing Democracy: Political Campaigning by Churches and Charities: Hazardous for 501(c)(3)s, Dangerous for Democracy, 95 Geo. L.J. 1313, 1315-16 (2007). Art Pine, Inquiry Finds No IRS Wrongdoing in Audits; Taxation Congressional Panel Finds No Evidence that Conservative Groups Were Purposely Targeted. An Improper Inquiry by Gore's Office Cited, Los Angeles Times, Mar. 16, 2000, at A16. See also infra note 222 and accompanying text.

222 See Treasury Inspector General for Tax Administration, Review of the Exempt Organizations Function Process for Reviewing Alleged Political Campaign Intervention by Tax Exempt Organizations (February 2005, Reference Number: 200510-035). See also Pine, supra note 221.

223 See IRS, Final Report, Project 302, Political Activities Compliance Initiative (hereinafter "2004 PACI") (discussing the method used to identify, review, and, where appropriate, sanction 501(c)(3) groups possibly engaging in prohibited activity in the 2004 election); IRS, 2006 Political Activities Compliance Initiative. The PACI review for the 2008 election cycle is still in progress. For the reports issued in connection with the 2004 and 2006 election cycles and materials related to the 2008 review, see http://www.irs.gov/charities/charitable/article/0,id=179738,00.html. See also infra note 224.

224 See, IRS, Political Activities Compliance Initiative; Procedures for 501(c)(3) Organizations, at http://www.irs.gov/pub/irs-tege/paci_procedures_feb_22_2006.pdf.; 2004 PACI, supra note 223. 
prohibition would be examined using more than the rational relation test, since the nature of these claims can be conceptually distinguished from the existence of a subsidy. ${ }^{225}$ In that event, the extent of the prohibition's vagueness or overbreadth is likely to influence, if not determine, whether a court would subject the prohibition to heightened scrutiny. The notice provided to organizations and guidance available to enforcement personnel in connection with the political prohibition can in no way be compared with the vagueness of the standards at issue in Big Mama Rag in at least two respects. First, the difference between the regulations in the two situations is especially clear with respect to the extent of vagueness or overbreadth. In Big Mama $R a g$, it was not even obvious to the court which organizations were subject to the "full and fair" test to begin with, in addition to the fact that there was no written guidance elaborating the meaning of "full and fair" once applied. ${ }^{226}$ In contrast, there are more than a dozen Revenue Rulings addressing the meaning of the political prohibition, many of which describe and analyze multiple fact patterns, ${ }^{227}$ as well as a few judicial decisions. ${ }^{228}$ Although the prohibition is enforced through a facts and circumstances test, there is thus a significant amount of precedential guidance to assist both organizations that seek to stay on the right side of the line and IRS personnel seeking to enforce the standard properly. ${ }^{229}$ The information contained in these sources has been reproduced in plain language guides in a wide assortment of pamphlets, brochures, and memoranda produced by law firms and advocacy organizations, many of which are available for free on the internet. ${ }^{230}$ That the amount of guidance

225 Vagueness/overbreadth claims are, however, related to the subsidy issue since, but for the desire to acquire or retain a subsidy, there would be no tax law consequence for misinterpreting the reach of the political prohibition.

226 See Big Mama Rag, supra note 212.

227 See supra notes 29, 32, 39-41and accompanying texts; Kindell \& Reilly, supra note 28. A large part of this guidance was issued in the last decade.

228 See supra notes 14, 26, 32, and accompanying text and Christian Echoes Nat'l Ministry, Inc. V U.S., 470 F.2d 849, 856 (10 ${ }^{\text {th }}$ Cir. 1972), cert. denied, 414 U.S. 864 (1973). See also American Campaign Academy v. Comm'r, 92 T.C. 153 (1989); Kindell \& Reilly, supra note 28.

229 There is also considerable non-precedential guidance in the form of private letter rulings issued to individual taxpayers, IRS Fact Sheets, Field Service advisories, PACI reports, and Exempt Organizations Continuing Professional Education (CPE) Technical Instruction Program essays used for training IRS personnel. All of these materials are available on Lexis and Westlaw.

230 Some illustrative examples are a series of advisories produced by the Alliance for Justice (AJF), located in Washington, D.C., and available at http://www.afj.org/fornonprofits-foundations/resources-and-publications/about-advocacy-election.html;

National Council for Nonprofits, available at http://www.councilofnonprofits.org/elections\#IRS; OMB Watch, available at http://www.ombwatch.org/node/9627; James Bopp, Jr., Guidelines for Political Activities for Churches and Pastors, available at http://www.mccl.org/Document.Doc?id=177; James Bopp, Jr., Guidelines for Political 
explaining the political prohibition is "significant" does not mean it is optimal. Optimal would be detailed regulations, replete with illustrations, as exist to determine what constitutes lobbying when a section 501(h) election is in effect. ${ }^{231}$ Yet, given the complexity and variety of methods of campaign activity, this may well be a situation in which the constitutional protection afforded speech must take into account "whether it would have been practical to draft more precisely."232

Second, as important as the quantity of guidance for interpreting the political prohibition is the fact that the criteria contained in the guidance are largely objective. For example, the Service's determination depends upon such things as whether voting records are distributed on an annual basis at the close of legislative sessions or their distribution is timed to an election, whether communications about legislative issues are targeted to election periods and concentrated in swing states where those issues are identified with specific candidates, whether all candidates are invited to candidate forums, whether voter guides based upon candidate surveys reproduce the candidates' words accurately, whether partisan voter guides are distributed on the organization's premises or on the public sidewalks outside their control, and the like. ${ }^{233}$ This contrasts with Big Mama Rag, where the standard in the regulations required the IRS to determine if a newsletter's articles were "full and fair" "based upon an individualistic-and therefore necessarily varying and unascertainable-standard the reactions of members of the public."234 Importantly, in contrast to the situation in Big Mama Rag, ${ }^{235}$ the political prohibition is not ambiguous at all about the entities covered by its strictures.

Some of the criteria contained in the political prohibition are, however, subjective. For example, depending upon the context, the IRS will examine whether the format or questions at a candidate forum reveal bias, whether the questions asked in a candidate survey are too concentrated in a single subject area, suggesting bias, or whether a communication made on the eve of an election improperly conveys a view as to a candidate's fitness for office. Considerations such as these inject an element of uncertainty into the analysis that is troubling from a First Amendment perspective because, as a practical matter, they may impose a burden of restraint on would-be actors during an election who desire to engage in political speech or other election related activities. The presence of such subjective criteria in such an important area

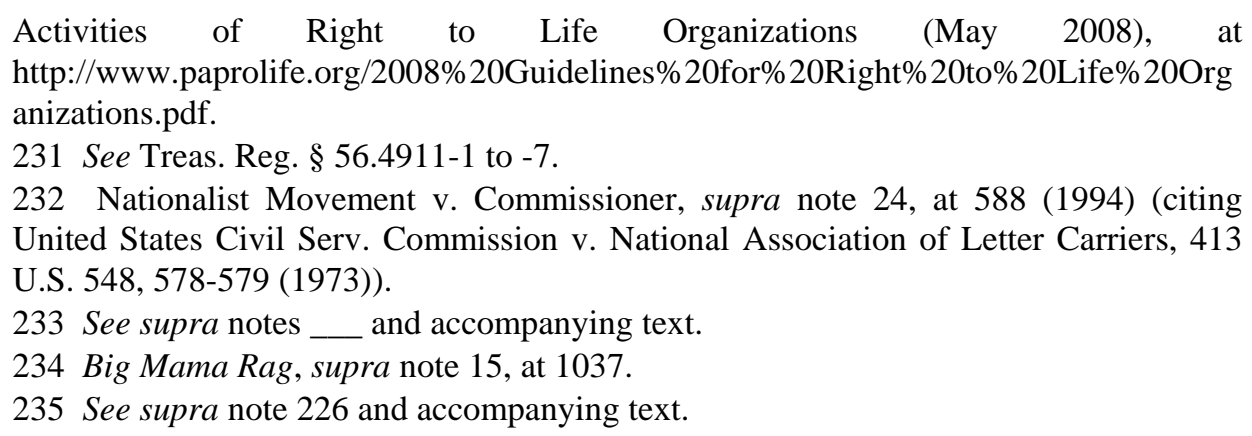


of constitutional law might trigger the application of heightened scrutiny to the potential vagueness and associated overbreadth of the political prohibition.

The fact that the political prohibition does not discriminate on the basis of viewpoint and that the scope of the standard is not open-ended, as were the regulations implicated in Big Mama Rag, suggests that the prohibition would be subject to intermediate scrutiny, if the rational relation test is deemed too lenient for the vagueness and overbreadth threat to political speech. That intermediate scrutiny would be used, rather than strict scrutiny, if heightened scrutiny is employed, is also suggested by the circumstance that most of the campaign finance cases employing strict scrutiny involved criminal sanctions. For example, in invalidating the political expenditure cap in Buckley, the Supreme Court noted that "[c]lose examination of the specificity of the statutory limitation [on independent expenditures] is required where, as here, the legislation imposes criminal penalties in an area permeated by First Amendment interests.”236 The Court characterized vagueness in statutes with criminal sanctions as "particularly treacherous." ${ }^{237}$ The Supreme Court's opinion in Wisconsin Right to Life was similarly concerned that the penalty for violating the law was criminal prosecution and criminal penalties. ${ }^{238}$ Likewise, for the Citizens United majority, the "threats of criminal liability and the heavy costs of defending against FEC enforcement” facing corporations seeking to engage in political activity during elections made the source rules in FECA analogous to prior restraints on protected speech. $^{239}$

Violations of the political prohibition are not usually subject to criminal sanctions. In the worst case, the IRS could impose revocation of an organization's exemption and a civil tax penalty. ${ }^{240}$ For a 501(c)(3) group, an excise tax of ten percent of the amount spent on communication(s) determined to be campaign intervention could be imposed on the organization, and a $2 \frac{1}{2}$ percent tax could be imposed on the managers who made the decision, unless their action was not willful and was due to reasonable cause. ${ }^{241}$ As the IRS's recent enforcement push reveals,

236 Buckley., supra note 34, at 40-41. See also id. at 41 n.47 and supra note 225.

237 Buckley., supra note 34, at 76.

238 See WRTL, supra note 11, at 468, 468, 493 (127 S. Ct. at 2666, 2666, 2680). See also McConnell, supra note 39, at 323, 330 (Kennedy, J., concurring in the judgment in part and dissenting in part).

239 Citizens United, supra note 13, at *43-*44.

240 A 501(c)(4) organization would then be reclassified as for-profit and owe back taxes and interest.

241 See I.R.C. § 4955(a). Under existing interpretation of willfulness and reasonable cause, it is unlikely that many decision makers would be subject o the manager's tax. See the description of the sanctions imposed so far on violations occurring in the last three election cycles in the PACI reports, supra note 223. Note, however, that the amount of the excise taxes can be doubled to 100 percent and 50 percent, for the organization and managers respectively, if the violation is not corrected. See id. § 4955(b). Correction means "recovering part or all of the expenditure to the extent 
however, revocation is rarely proposed and it has only been imposed if violations are flagrant or repeated. ${ }^{242}$ As the PACI Reports also reveal, most organizations found to have engaged in prohibited campaign activity have received only written advisories, even though the violation included such clearly prohibited activities as contributing money to a candidate or posting campaign signs on the organization's premises. ${ }^{243}$ Even when excise taxes have been imposed, the Service frequently refunds the tax as well as interest and penalties, if any, if the organization corrects the violation. ${ }^{244}$ Further, revocation relating to one or more years of an organization in no way precludes it from having its exemption restored in exchange for agreeing to abstain from campaign activities. All of these considerations bear on how chilled an organization's speech is likely to be as a result of the political prohibition. Although civil fines can impose burdens on the affected entities, the burden is qualitatively different from and usually far less extreme than what is entailed by criminal sanctions.

Under the intermediate scrutiny standard of judicial scrutiny, Congress would have to demonstrate that the purpose of the political prohibition "furthers an important or substantial" interest, is "unrelated to the suppression of free expression," and needs the prohibition for its goal to be implemented "effectively."245 All of the interests furthered by the political prohibition should be considered substantial: preventing deductible charitable contributions from being used to fund political activities, assuring that only organizations devoted exclusively to a charitable mission are selected to benefit from public funding, preventing tax favored charities from dissipating their time, energy, and concentration on partisan activities, and preventing charities from engaging in activities with a high risk of furthering the private benefit of individuals and candidates for public office.

The means chosen by Congress to address these concerns may be more controversial. As was noted earlier, if preventing public funds from subsidizing campaign activity is seen as the sole government interest, it may be possible to construct a mechanism involving an affiliated entity to reduce this risk. ${ }^{246}$ Even so, it is difficult to predict whether the political prohibition would be found constitutionally

recovery is possible, establishment of safeguards to prevent future political expenditures, and where full recovery is not possible, such additional corrective action as is prescribed by the Secretary by regulations.” Id. 4955(f)(3).

242 See 2004 and 2006 PACI reports, supra note 223; Branch Ministries, supra note 15 (revoking the exemption of a church that had placed a full-page advertisement in two national newspapers urging Christians not to vote for Bill Clinton for President).

243 See supra note 223.

244 See Catholic Answers, supra note 15, at *7-*8 (Lexis pages); Complaint, Christian Coalition of Florida, supra note 15, ๆ 43-44. Numerous commentators have remarked on the lax enforcement by the IRS. See, e.g., Keith S. Blair, Praying for a Tax Break: Churches, Political Speech, and the Loss of Section 501(c)(3) Tax Exempt Status, 86 DENV. U.L. REV. 405, 428-29 (2009).

245 See supra notes 122-122 and accompanying text. 246 See supra notes 178-179. 
infirm for this reason, given that intermediate scrutiny does not require government to select the least restrictive means to achieving a statute's purpose. Further, taking into account considerations such as keeping charities' focus on their charitable mission and out of partisan activities, the ability of a 501(c)(3) organizations to partner with affilated 501(c)(4) groups that engage in campaign activity could well satisfy the standard of being narrowly drawn to achieve the entire range of statutory purposes.

\section{CONCLUSION}

The preceding analysis is inconclusive. A direct attack on the constitutionality of the tax law prohibition on 501(c)(3) groups' political campaign activity is unlikely to succeed, even though the tax law restriction applies to a far wider range of campaign activities than is permitted for campaign finance law. ${ }^{247}$ The key differences in the constitutional analysis of the prohibition under tax law, as compared with the counterpart analysis of restrictions on political speech under campaign finance law, suggest that minimal judicial scrutiny will be applied to the former and that both the government's purpose in limiting political activity for charities and the means chosen will be found reasonable.

The outcome with respect to a vagueness or overbreadth challenge to the terms of the prohibition, as implemented by the IRS and the courts, is more uncertain. Among other reasons, there is the possibility that intermediate scrutiny would be employed rather than the rational relation test. Even in that event, it is likely that some, if not all, of the government interests discussed in Part IV would be considered substantial. In contrast, there is some uncertainty as to the ability of the political prohibition to qualify as narrowly enough drawn to achieve the statute's purpose. In particular, the prohibition's validity in this respect may turn on whether a reviewing court accepts the validity of linking the prohibition to goals other than preventing deductible charitable contributions from financing campaign activity.

I would distinguish what I believe is a fair reading of the constitutional tax law jurisprudence and what might happen if the political campaign prohibition makes its way to the Supreme Court. Five of the current Justices have made crystal clear their aversion to anything that purports to interfere with the free exercise of political speech. It is possible that they could disregard the weight of the precedents described in this paper, invoking other entrenched constitutional doctrines, for example, that the government should not be permitted to do indirectly what it cannot do directly. They might argue that Massachusetts Citizens for Life has superseded Taxation with Representation, relegating the distinction expressly made by the Supreme Court in

247 This Article has confined itself to the constitutional dimensions of the political prohibition. For a thorough analysis of the public policy reasons for the prohibition, focusing on the dangers that would result were 501(C)(3) groups to engage in campaign activity, see Tobin, supra note 221. 


WHEN STATUTORY REGIMES COLLIDE 44

that case $\mathrm{e}^{235}$ to mere dictum in a footnote. In that event, the alternate channel doctrine blessed in Taxation with Representation would no longer be good law, and exempt organizations, like organizations in general, could not have their political speech regulated to a greater degree than is permitted by Buckley, as interpreted by Wisconsin Right to Life and Citizens United. As remote as that possibility may seem, taking into account that three Justices are already on record as prepared to overrule Buckley altogether, ${ }^{236}$ uncertainty in this area is all that is really certain.

235 See supra notes 163-164.

236 See Randall v. Sorrell, 548 U.S. 230, 265-266 (Thomas, J. Joined by Scalia, J., concurring); Nixon v. Shrink Mo. Gov't Pac, 528 U.S. 377, 409-410 (2000). (Kennedy, J., dissenting). 